DE ECONOMIST 157, NO. 1, 2009

\title{
HOUSING WEALTH AND HOUSEHOLD PORTFOLIOS IN AN AGEING SOCIETY
}

BY

\author{
JAN ROUWENDAL*
}

\begin{abstract}
Summary
Housing is one of the most important consumption goods, also for the elderly. For owner-occupiers, housing equity is moreover usually the most important asset in their investment portfolio, and hence, household wealth of the elderly is extremely sensitive to developments on the housing market. This panel paper surveys the literature on housing as a consumption good and asset category over the life cycle and moreover presents stylised facts on the housing market behavior of Dutch households over their life cycle. Although many of the issues discussed also occur in other countries, the Dutch housing market is used as a background o the review.
\end{abstract}

Key words: ageing, borrowing constraints, household financial behavior, housing market, housing wealth

JEL Code(s): D12, D14, D91, R21

\section{INTRODUCTION}

Housing is one of the most important consumption goods: most households spend a sizable fraction of their consumption expenditure on rent or out-ofpocket user costs, notably mortgage interest. For owner-occupiers, housing equity is usually the most important asset as well, although many owneroccupiers have assumed a large mortgage loan. House prices and interest rates are subject to changes, and recent developments on the American housing market have reminded us of the fact that a house can be a vulnerable property.

Since home equity is usually the largest component in the investment portfolio of an owner-occupier, household wealth is extremely sensitive to housing-market developments. In the recent past, the prolonged period of house price increases contributed to the impression that housing is a safe investment with high returns, but the developments of the early 1980s demonstrated that other scenarios are also possible. The combination of a substantial increase in real interest rates and an economic recession may occur again

* Corresponding author: Department of Spatial Economics, VU University, De Boelelaan 1105, 1081 HV Amsterdam, The Netherlands; e-mail: jrouwendal@feweb.vu.nl. 
in the future. This would probably lead to a substantial drop in house prices - implying almost overnight the disappearance of large amounts of housing capital.

Although this paper does not aim to discuss the (un)likelihood of such dramatic events, it does attempt to shed some light on the determinants of housing demand and, through this, to generate insight into the way households deal with the constraints and opportunities they encounter on the housing market. The modest purpose of highlighting some of the insights offered by the economic literature on household behavior with respect to housing should, nevertheless, be expected to increase our understanding of the likelihood of specific events and perhaps of policy measures that can be taken to avoid undesirable developments.

Section 2 sets the scene by discussing some stylized facts about the Dutch housing market on the basis of the recently collected WoON06 data. This intends to provide some context for the review that follows. Although the Dutch housing market has some specific characteristics that distinguish it from that in other countries, many of the phenomena highlighted in this section are also present in other countries. ${ }^{1}$ Two interesting examples are that many middle-aged owner-occupiers have assumed two or more mortgage loans, and that elderly owner-occupiers often live in large houses with large amounts of equity and low out-of-pocket housing costs. The supply side of the Dutch housing market is quite different from that in other countries, but since this review focuses on demand this hardly decreases the usefulness of the Netherlands as an illustration.

Using the economic literature as a starting point, Section 3 considers how borrowing constraints related to housing affect household behavior. At the beginning of their life cycle, would-be homeowners are constrained by a down-payment requirement or a maximum mortgage-payment-to-income ratio. Households may deal with these restrictions in various ways: by saving more, by supplying more labor, by starting with a smaller dwelling or by staying longer in the parental home. The mortgage industry has also proved helpful in developing new types of mortgages that have lower initial payments, usually making more intensive use of tax facilities such as the deductibility of mortgage interest payments. At the end of the life cycle, housing equity is rather illiquid, which seems to result in the postponement of its consumption or its bequest - even though the relevant borrowing constraints at that time seem less severe and can in any case be relaxed by downsizing housing consumption or moving to the rental sector. Although the distortionary effects of borrowing constraints have attracted much attention in the literature, we note that they also protect lenders and borrowers against assuming too much risk.

1 A comparative study of developments in different countries is clearly outside the scope of this paper, but could be undertaken with the SHARE data. 
Sections 4 and 5 discuss the effects of risk and uncertainty on housing demand. One specific aspect of housing is that it functions simultaneously as consumption good and as asset. This dual role imposes a constraint on the asset portfolio of the owner-occupier that diminishes his ability to diversify risks. Although this observation has evoked some ingenious suggestions for the development of financial instruments that would solve this problem, a market for such housing-based financial derivatives has not (yet) been developed. The homeowner's exposure to risk is increased even further when he postpones repaying the mortgage and invests his money in assets promising a higher (but uncertain) return, as is attractive in the current Dutch tax system.

It is worthwhile to note here that a house is much more than a source of risk. An outright owner, in particular, obtains from his house a steady and certain flow of services at low out-of-pocket cost. This observation sheds light on the position of many elderly homeowners. The picture becomes even more complete if we add the health and mortality risks that figure prominently for this age group, and observe that many elderly homeowners use housing equity as a buffer for uncertain medical expenses down the road.

Throughout the paper we take a life-cycle perspective in a double sense. The next section presents some global information about the housing situation of the Dutch population by plotting a number of relevant variables as a function of the age of the head of household. This information serves as an empirical background for the economic analyses that will be reviewed in subsequent sections. Most of these analyses take the life-cycle hypothesis briefly, the idea that households are intertemporal utility maximizers - as their analytical framework, and this is the second sense in which we take a life-cycle perspective.

As noted above, the emphasis in what follows will be on the demand side of the housing market. The reader should therefore keep in mind throughout that most of the studies that will be discussed take house prices as given and ignore - potentially large - general equilibrium effects.

\section{SOME STYLIZED FACTS}

This section presents some descriptive evidence on housing-market behavior of Dutch households over the life cycle. This provides a backdrop for the survey of economic literature that follows. It should be clear from the outset that in the present section we use the life-cycle concept not in the formal sense of intertemporal utility maximization, but as a descriptive device for organizing data on housing over the life course of individuals. The data are those of WoON06, an extensive survey dataset (approximately 64,000 respondents) that contains information about housing and related variables of the Dutch 
population in $2006 .^{2}$ WoON 2006 is in many respects similar to the Housing Needs Surveys that took place in 4-year intervals between 1994 and 2002. Data collection for WoON 2006 took place on behalf of the Dutch ministry of housing. ${ }^{3}$

It is important to keep two general aspects of these figures in mind when reading this section. The first is that the lines refer to averages over numbers of respondents of a particular age that become smaller at higher ages. ${ }^{4}$ The result is that the means become more volatile for higher ages. The second aspect to keep in mind is that all figures refer to cross-sections. Although this should be self-evident from the source of the data, experience shows that it is highly suggestive to interpret them as referring to developments over time. This can be misleading when cohort effects are present in the data, as is probable for most of the pictures shown below. The discussion will sometimes refer to such effects explicitly, but even if it does not, the reader should be aware of their possible presence.

\subsection{Renting and Owning Over the Life Cycle}

Figure 1 shows the share of owner-occupied households as a function of the age of the head of household. Homeownership increases steeply with age for heads of households in their twenties, and then levels off just above $60 \%$ and decreases with age for heads of households above 55 years of age. The share of renters is always at least one-third.

Rouwendal (2007b) provides some information about cohort effects that shows that homeownership among the younger, but especially among the elderly, households has increased markedly over time. This suggests that in the next decade homeownership rates among households in their sixties will also be above $60 \% .^{5}$

\subsection{Tenure Choice, Income and Labor Supply}

Homeownership is not just a matter of taste that is idiosyncratically distributed among households. It is systematically related to a number of other important life-cycle variables, such as income and household labor supply. This is illustrated by the three graphs presented in this subsection.

2 Cross section data like those of WoON 2006 have well known limitations. Panel data the DHS, see www.centerdata.nl - are also available for the Netherlands, but the size of this sample is quire small, and it is not representative for the Dutch population at large.

3 For more information and ordering the data see: www.vrom.nl/infowonen.

4 The age is the age of the head of the household (as indicated by the households). All figures refer to ages between 25 and 85 .

5 See van der Schors et al. (2007) for an analysis of these cohort effects. 


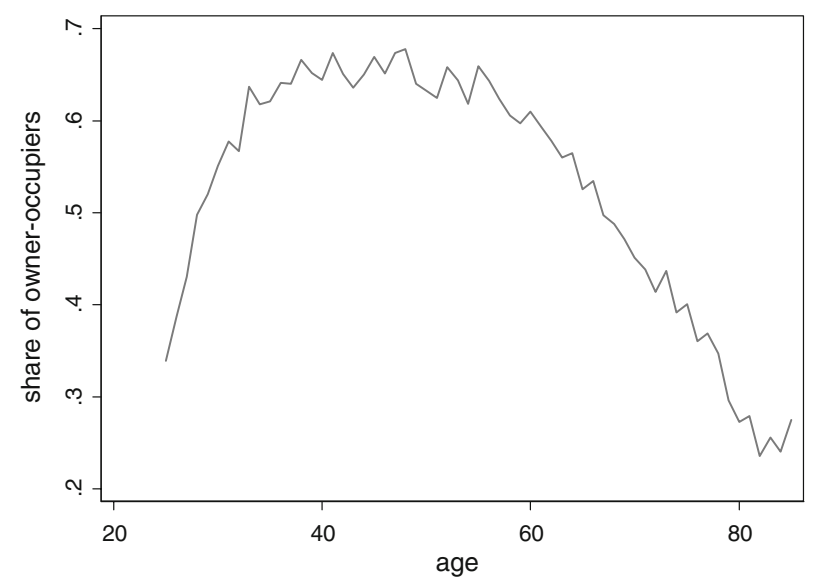

Figure 1 - Share of owner-occupiers and age of the head of household. Source: own computations based on WOON06

Figure 2 shows the net monthly household income ${ }^{6}$ of renters and homeowners as a function of the age of the head of household. On average, the income of homeowners is much higher than that of renters. Moreover, the pattern of income over the life cycle is different for the two groups: for renters, average income remains almost constant after they pass their twenties, whereas for owners it peaks around 50 years of age. At higher ages the difference becomes much smaller.

The diverging income patterns of renters and owners are related to differences in labor supply between those groups. Figure 3 shows that the share of two-earner households is much higher among the homeowners than it is among the renters. ${ }^{7}$ It should be noted that this does not necessarily imply a causal relationship from earning capacity to homeownership. It may well be that the desire to buy a house stimulates labor supply, and in particular that of a second person in the household. ${ }^{8}$ Figure 4 shows the number of hours worked by (adult) household members ${ }^{9}$ as a function of the age of the head of household. The pattern is very close to that of the share of two-earner households.

A comparison of Figure 2 with Figures 3 and 4 shows that the income of homeowners peaks later than the share of dual earners and the number

6 It is the sum of the net incomes of the interviewed person and his or her partner when present.

7 The reference group is all households with less than two earners, including singles.

8 See the discussion in Section 3.5.

9 The figure indicates the sum of the number of hours worked by the head of household and his/her partner, when present. 


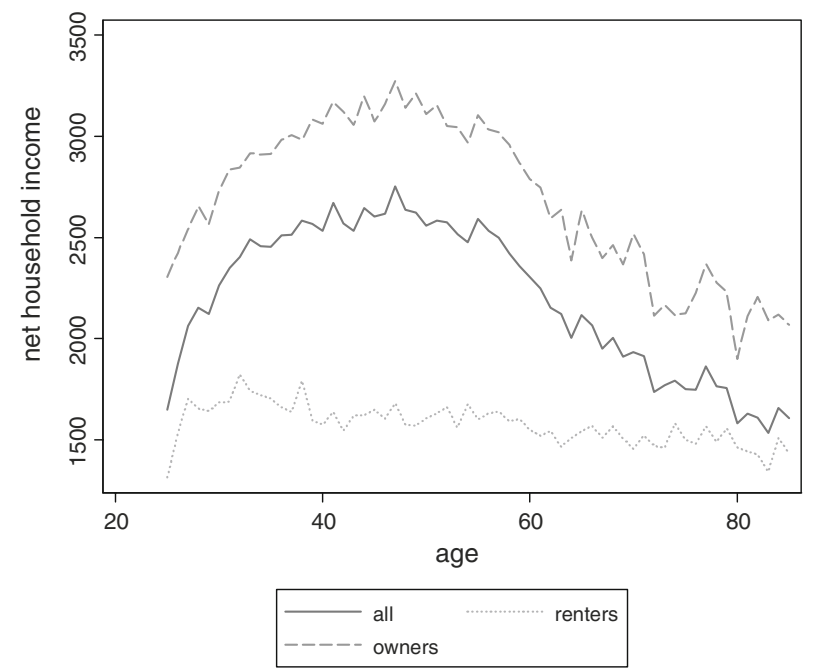

Figure 2 - Household income and age of the head of household. Source: own computations based on WOON06

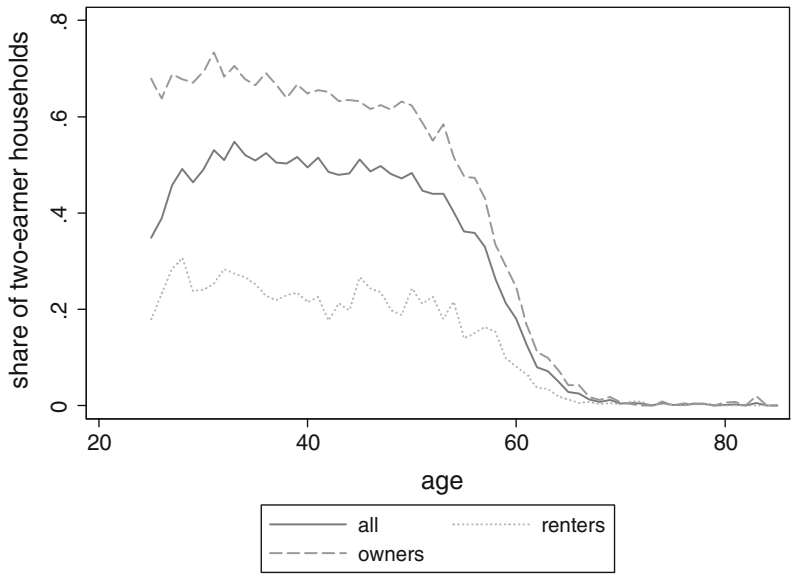

Figure 3 - Share of two-earner households and age of the head of household. Source: own computations based on WOON06

of hours supplied. Apparently, homeowners often realize increases in their hourly wage rate after having participated on the labor market for a number of years. This may be related to a higher level of education and an associated ability to continue accumulating human capital after entering the labor market. Renters seem to lack this ability, or move to homeownership as soon as their income rises. 


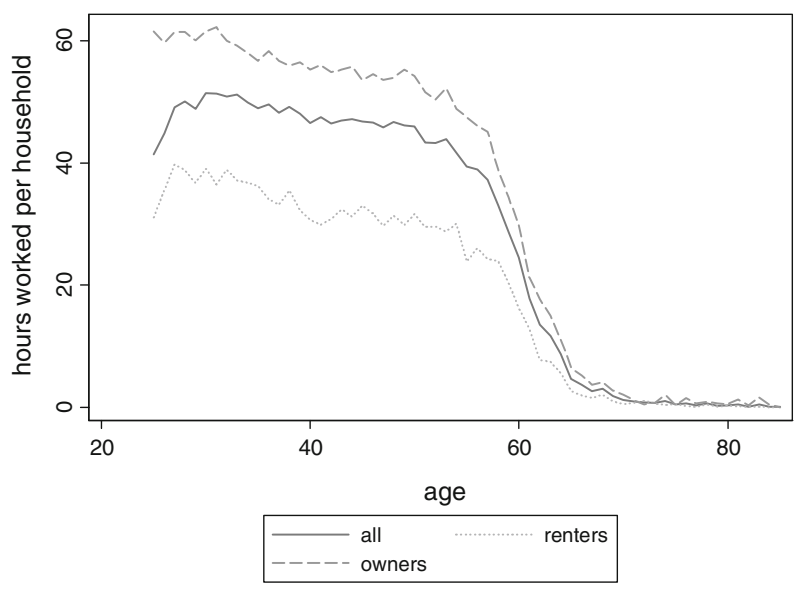

Figure 4 - Hours worked per household and age of the head of household. Source: own computations based on WOON06

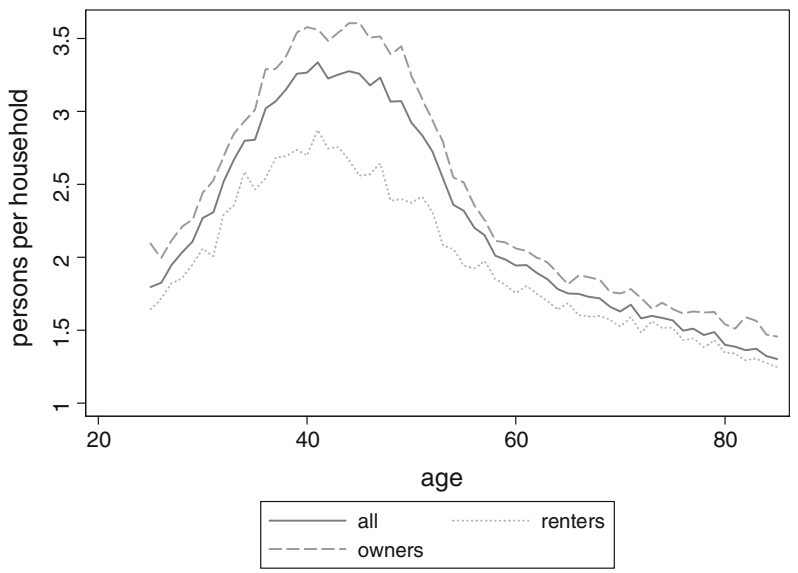

Figure 5 - Household size and age of the head of household. Source: own computations based on WOON06

\subsection{Household Composition and Housing Demand}

Owner-occupiers differ from renters not only in their labor supply, but also in household composition. Figure 5 shows the average number of persons of owner-occupied and rental households ${ }^{10}$ as a function of the age of the head of household. Homeowners have larger households than renters throughout

10 The figure refers to the number of persons currently living in the household. 


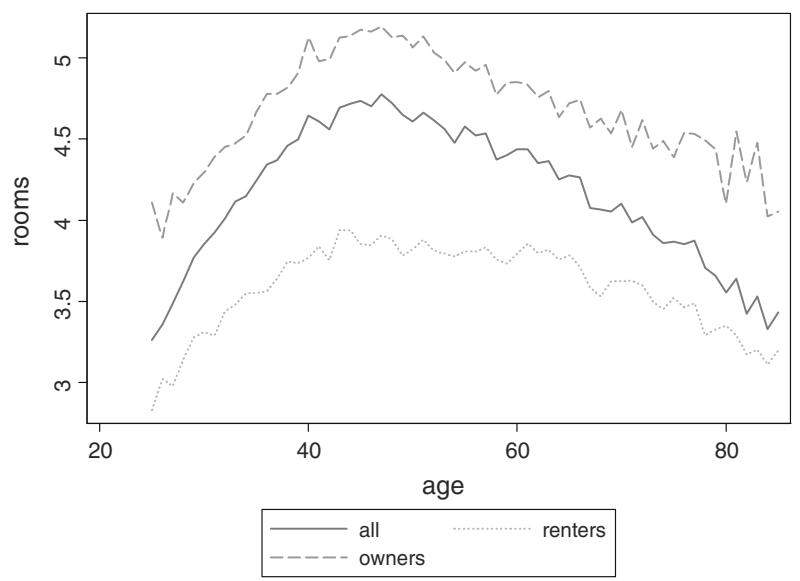

Figure 6 - Number of rooms and age of the head of household. Source: own computations based on WOON06

the life cycle. The larger share of renters among single households may explain part of the difference; the remaining difference can be attributed to the presence of children. It may be noted that there are probably not only differences between the number of children ever born in owner-occupied and renting households, but also between the ages at which these children leave the parental home. And also here, one should be aware of the possible presence of cohort effects as the average age at which women give birth has increased over time.

The difference in household size is especially large for households in their thirties and forties, and decreases when children leave the parental home.

Figure 6 shows that the pronounced changes in household size over the life cycle are only partly reflected in the development of the number of rooms available. Owner-occupiers live in larger houses than renters do, and the average size of the houses of both groups reaches a maximum just above age 40 , but the changes in house size are much more gradual than the changes in household size.

As a consequence of these differing developments, the number of rooms per household member is low during the early stages of the life cycle, and increases when the share of 'empty nests' grows as household heads reach their fifties or sixties. Figure 7 shows that the number of rooms per person is somewhat higher among middle-aged renters than owners, ${ }^{11}$ but the gap between the amount of space used by owner-occupiers and renters increases in age.

11 This probably has much to do with the higher share of singles among renters. 


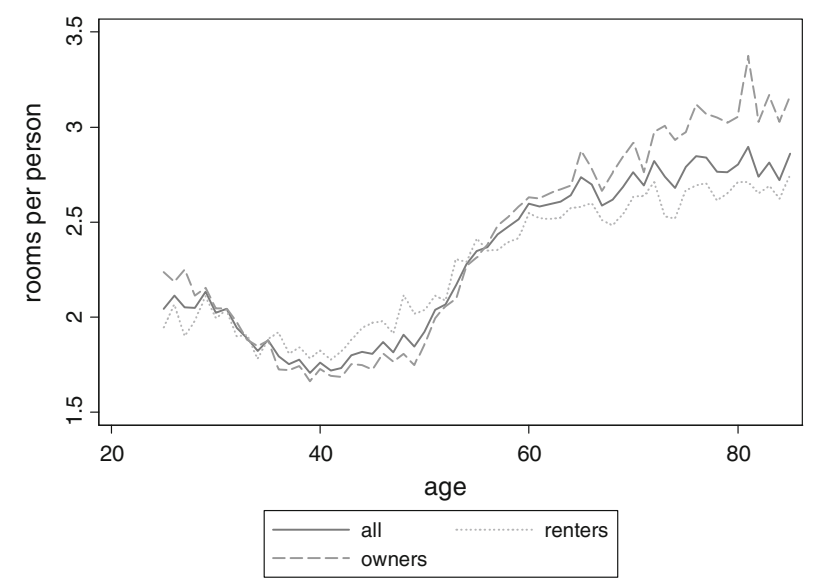

Figure 7 - Rooms per person and age of the head of household. Source: own computations based on WOON06

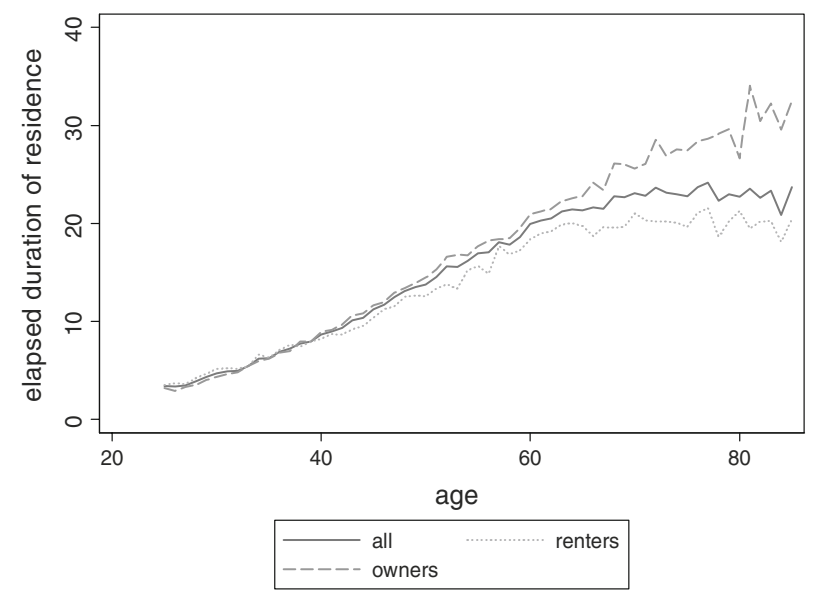

Figure 8 - Average elapsed duration of residence and age of the head of household. Source: own computations based on WOON06

\subsection{Mobility}

The relatively stable housing consumption (as measured in the number of rooms) is related to the relatively low housing mobility. Figure 8 shows the elapsed duration of residence of renters and owners at the moment that the interview for WOON06 took place. This elapsed duration is low when the head of household is young, and increases with age. 


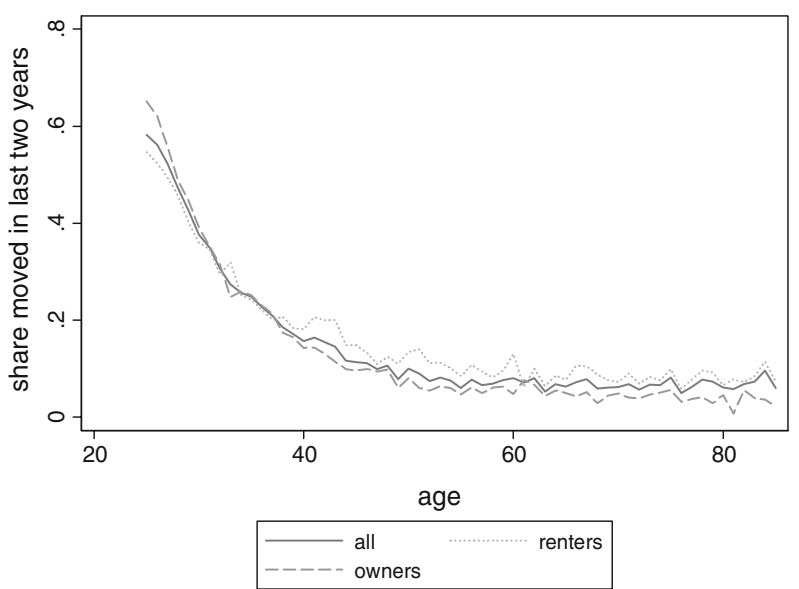

Figure 9 - Housing mobility and age of the head of household. Source: own computations based on WOON06

Again, note the diverging development among elderly homeowners and renters. Whereas the elapsed duration of residence stabilizes among elderly renters, it continues to increase among owners.

Figure 9 shows the corresponding pattern of mobility. It pictures the share of renters and owners that have moved to their present housing in the 2 years preceding the WOON06 interview. For homeowners in their twenties, this recent mobility is larger than for renters in the same age class, as should be expected on the basis of the steeply increasing share of homeownership. For all other age classes, however, renters are more mobile than owners.

\subsection{Mortgages}

Most owner-occupiers financed the purchase of their house partly or completely with a mortgage loan. Figure 10 shows the average number of such loans taken by an owner-occupier as a function of age. The figure shows that this average is larger than 1 for owner-occupiers under 60 years of age. Taking into account that assuming two mortgages at once would be exceptional ${ }^{12}$ (because of the transaction costs involved), many households took a second mortgage after they first became owner-occupiers. Presumably this often happens when the household moves to another house, or decides to improve the house.

12 Combinations of mortgage types have recently become popular in the Netherlands. Such combinations were included as a single mortgage loan in the computations underlying Figure 10. 


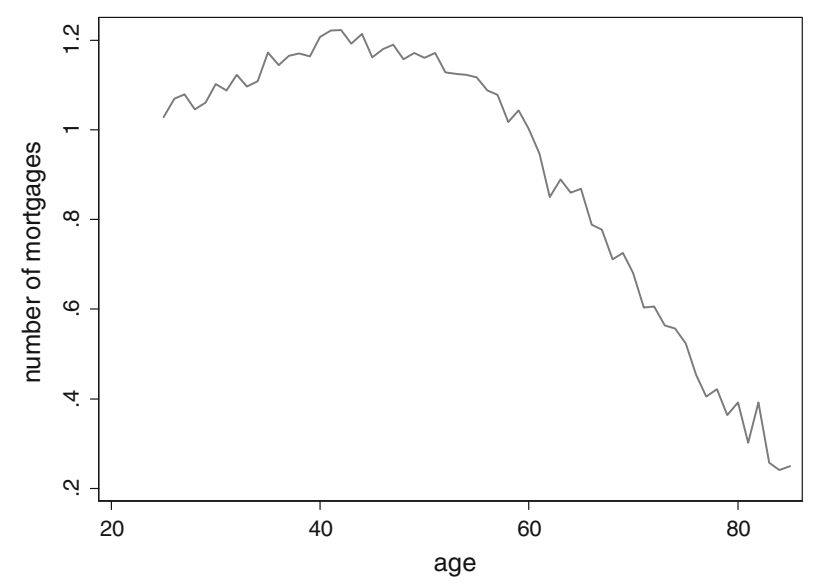

Figure 10 - Average number of mortgage loans (of owner-occupiers) and age of the head of household. Source: own computations based on WOON06

Since most mortgage types are self-amortizing, it is not surprising that the number of mortgages falls with the age of the head of household. In view of the large elapsed duration of residence of most elderly owner-occupiers, the relatively slow decrease of the average number of mortgage loans is the more surprising aspect of Figure 10. Note, for instance, that if the head of household is 70 years old, the average number of mortgages is still approximately 0.5 .

Figure 11 shows the current value of the house, ${ }^{13}$ the original price paid and the outstanding value of the mortgage loan. It shows that the value of the outstanding mortgage loan is very close to the price originally paid, until the head of household is approximately 60 years of age. If the head of household is older, then the outstanding value is usually smaller than the price originally paid, although the difference increases slowly.

Most owner-occupiers feel that the current value of their house is substantially higher than the price they paid for it. This means that the investment in their house has generated a considerable return. It is not surprising that this is especially true for the elderly owner-occupiers, who often purchased their current dwelling a long time ago - in many cases before the surges in house prices of the 1990s. 


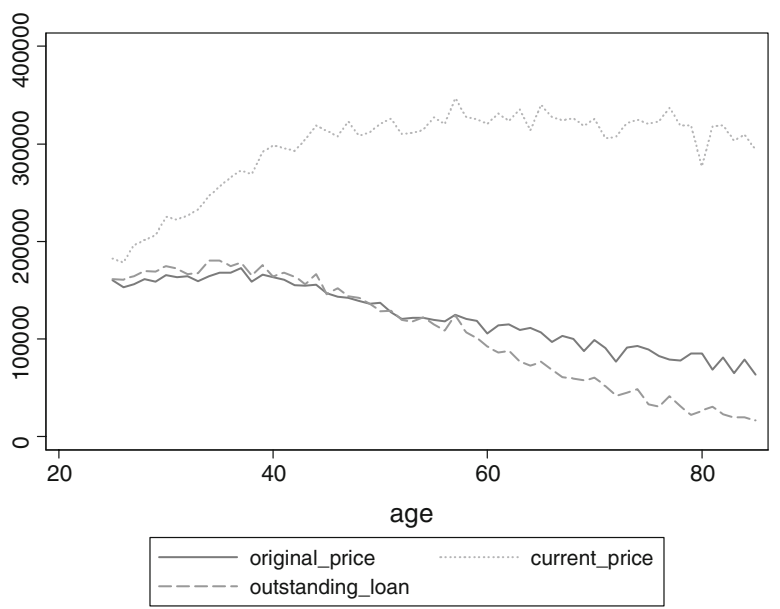

Figure 11 - Original price, current price, outstanding mortgage loan and age of the head of household. Source: own computations based on WOON06

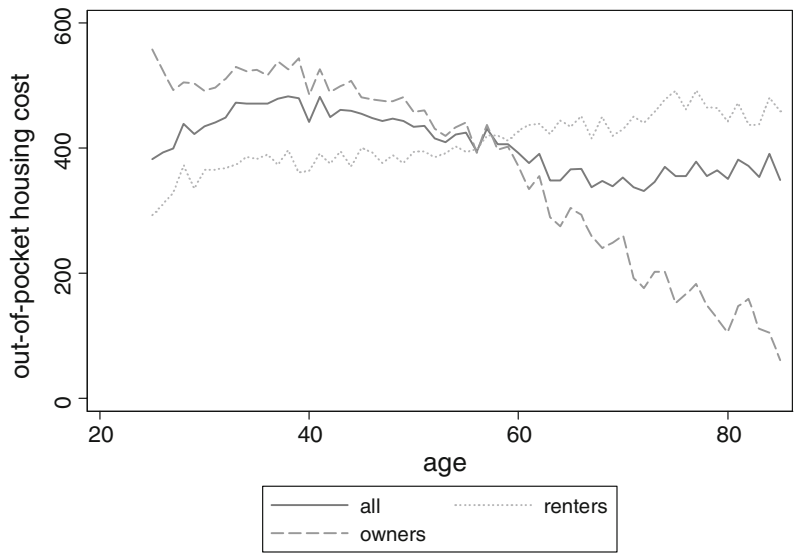

Figure 12 - Net out-of-pocket housing cost and age of the head of household. Source: own computations based on WOON06

\subsection{Out-of-Pocket Housing Costs}

Figure 12 shows the net out-of-pocket housing costs of renters and owneroccupiers. Although the net rent ${ }^{14}$ of the youngest renter households is somewhat lower than that of renter households with a head older than 30 ,

14 This is the difference between the actual rent and the rent allowance, formerly known as the individual rent subsidy. 
it does not change much with the age of the head of household. This is in sharp contrast with the difference between the net mortgage costs ${ }^{15}$ of owneroccupiers, which we have taken here as the indicator of their out-of-pocket housing costs. It appears that especially the very young owner-occupiers have very high mortgage costs. Although the difference decreases with the age of the head of household, net mortgage costs are on average higher than net rents for all owners below 60 years of age. For elderly households, however, net mortgage costs decrease dramatically with age, due to the fact that for many the mortgage is amortized sooner or later.

\subsection{Conclusions}

The information provided in this section is only meant to provide some basic background for the literature review that follows. The mains findings are as follows:

- Homeownership increases rapidly among young households, stabilizes at about $65 \%$ for middle-aged households and is lower among the elderly.

- The income of homeowners is on average substantially higher than that of renters; homeowners supply more hours of work, are more often twoearner households and realize increases in hourly wage rates longer than renters.

- Single-person households are overrepresented among renters, as are families with young children among owners; the number of rooms per person adjusts partially to household size for young- and middle-aged households, but empty nests usually imply a relatively large consumption of housing, especially among elderly homeowners.

- Mobility decreases with age and is exceptionally low among elderly homeowners.

- Most owner-occupied housing is financed in part by one or more mortgage loans, and even among elderly households mortgages are frequently present.

- For young- and middle-aged households the total size of the mortgage loan(s) is on average almost equal to the price they paid for their current house; for elderly homeowners it is smaller.

- Net out-of-pocket housing costs among young- and middle-aged households are highest for owner-occupiers; among elderly households, owners pay on average much less than renters do.

15 This is the difference between mortgage payments and the effect of the fiscal deductibility of mortgage rent paid on the amount of income tax paid by the household. 
The WOON06 database provides no information about other wealth components of households. Such information is provided in Alessie et al. (2002), to which we refer the interested reader.

\section{INTERTEMPORAL UTILITY MAXIMIZATION AND BORROWING CONSTRAINTS}

The previous section presented some suggestive evidence of the way in which households realize their demand for housing over the life cycle. In providing an economic interpretation of the observed behavior, the natural way to proceed is to adopt the hypothesis that actors attempt to optimize their wellbeing. The theory of intertemporal utility maximization, usually referred to as the life cycle- or permanent-income hypothesis, was developed in the 1950s and has continued to be a fruitful research area. Given the importance of housing as an asset and consumption good, it is somewhat surprising to learn that the mainstream of this literature pays hardly any explicit attention to this commodity ${ }^{16}$ There is, however, a separate branch of the literature related to urban economics that is concerned with various aspects of housing.

This section reviews the classical treatment of Artle and Varaiya (1978), who stressed that life-cycle theory's emphasis on the importance of the income flow over the entire life cycle as an explanatory variable for consumption decision was in the case of housing at least partly misplaced because important credit constraints are present. This analysis gave rise to a vast literature on the importance of borrowing constraints, the illiquidity of housing and associated restrictions on housing demand. Following the discussion of Artle and Varaiya's contribution is a more detailed treatment of a number of relevant topics that it suggested.

The discussion of this section has generally ignored the effects of uncertainty. The next section explores the consequences of incorporating this important phenomenon into the analysis.

\subsection{A Basic Life-Cycle Model}

Many households prefer to own the house in which they live. This basic preference for homeownership has to do with a desire to have a home as a place of one's own. Homeownership is often connected to the 'American dream' of freedom and independence, but it must be stressed that a basic preference for homeownership is not restricted to the US, but seems to be universally present. Although homeowners bear the risk of local house-price developments, experience substantial moving costs and must arrange for themselves

16 For instance, the authoritative review of Browning and Lusardi (1996) and the monograph by Deaton (1992) pay no attention to housing. There are-of course-exceptions to this rule. See, for instance, Coulibaly and Li (2006). 
the maintenance and temporary upgrading of the kitchen and the bathroom, they can take their decisions without having to negotiate with a landlord. At least for households who expect to stay for a prolonged period, homeownership seems to be the generally preferred type of tenure. ${ }^{17}$ Economic analysis has stressed the principal-agent problems involved in renting as a basic drawback of this tenure form (see Henderson and Ioannides (1983)). Homeowners have an incentive to maintain their property optimally, whereas renters do not. Renting thus tends to be more expensive than owning, which makes owning the preferred tenure type.

This is the basic position taken by Artle and Varaiya (AV), who provided a seminal analysis of the question why we see, nevertheless, so many renters around (Artle and Varaiya (1978)). The answer they provide stresses the effect of credit constraints on homeownership. In their model all housing is identical, but households have a basic preference for homeownership because of the lower housing costs involved. Housing costs of owner-occupiers are determined by an annuity mortgage with a given term and a given interest rate. This cost is lower than the rent that has to be paid for the same housing under the alternative tenure.

Households can borrow only a fraction, say $(1-k)$, of the value of their home as a mortgage loan. This means that unless they start their life with enough wealth, they have to rent and save all the while until they are able to meet this credit constraint. When a house has been bought, it is an illiquid component of the homeowner's wealth. The household is therefore unable to consume the equity it accumulates by paying for the mortgage unless it sells the house and returns to the rental sector. If the household does not want to bequeath all of its housing wealth, it must therefore become a renter towards the end of its life, so as to consume (part of) this equity.

AV's analysis provides an explanation for the simultaneous existence of a rental and an owner-occupied sector, although the former tenure type is inferior. It does so by introducing two new constraints, in addition to the usual budget constraint. The first of these constraints forces a household to accumulate wealth for the down payment. The second forces them to sell the house before being able to consume the accumulated equity. ${ }^{18}$ Both constraints have received further attention in the subsequent literature, which will be discussed later in this section.

The main message of AV's analysis is that the constraints associated with homeownership have substantial distortionary effects on the life-cycle consumption pattern of households. In particular, they stress that these

17 See Dietz and Haurin (2003) for an extensive review of the social and private benefits of homeownership.

18 Note that AV explicitly exclude instruments like reverse mortgages that would allow an owner to consume some of the housing equity without selling the house. 
constraints may cause discontinuities in the consumption path, which are typically such that (non-housing) consumption jumps upward at the moment a house is bought (and no further saving for the down payment is necessary) and at the moment at which it is sold (and consumption of the equity accumulated in the house can start). The analysis implies that consumption of homeowners is shifted towards later stages in the life cycle.

One of the main attractive features of AV's analysis is that it provides a simple explanation for the typical life-cycle pattern of tenure choice that appears, for instance, from Figure 1: renting is especially popular in the first and final stages of the life cycle, whereas ownership is the preferred type for middle-aged households. ${ }^{19}$ It must however, be realized, that Figure 1 refers to a cross section. A cohort analysis shows that ownership rates remain almost constant over time. AV's explanation of this element of the data was therefore less appropriate.

\subsection{The Down-Payment Constraint}

AV's analysis focused attention on the role of the down-payment constraint as a hurdle for would-be homeowners. The main reason for the presence of such a constraint is the default risk associated with a mortgage loan. If the homeowner has no equity, his housing risk is minimal. When house prices decrease, paying off the mortgage loan implies that the owner has to pay more for the house than the market price. He may therefore decide to 'walk away' from the home and leave the lender with the loss, while improving his own situation by buying a similar house at a lower price. This temptation for a homeowner is usually mitigated by moral considerations, which tend to be reinforced by reputational effects (notably, credit ratings) and sometimes also by legal sanctions that mitigate the temptation for such (overly) opportunistic behavior.

Nevertheless, lenders do not like a situation in which the value of the loan exceeds that of the collateral. An important reason is that if homeowners are unable to pay for the mortgage (for instance, because of unemployment or divorce), the consequences of default are similar, from the lender's perspective, as when the homeowners are unwilling. Since banks cannot (or only imperfectly can) distinguish the high-risk households from the low-risk ones, they tend to either refuse mortgages with a high loan-to-value ratio for any borrower (thereby introducing a down payment constraint), or put a penalty on such loans through a higher interest rate or an obligation to buy mortgage insurance, which is usually costly. The relationship between high loanto-value ratios and default risk has been confirmed by empirical evidence

19 It may be noted that AV's analysis also neglects some - at least potentially - important aspects of tenure choice, such as the difference in the cost of mobility of renters and owners. 
(see, for instance, Quigley and Van Order (1991), Deng et al. (2000)), which provides strong a priori evidence on the relevance of a down-payment constraint for housing demand.

Since prior to AV's analysis no one seemed to have paid any attention to the down-payment constraint, it took some time after AV's publication before the constraint came to be generally accepted as an important feature of demand for owner-occupied housing. Brueckner (1986) highlighted its role by providing a simplified analysis in a two-period setting. Plaut (1984) analyzed a model in which the mortgage interest rate contains a leverage premium, which leads to a soft version of the down-payment constraint.

Empirical analysis started in the 1990s. Jones (1990) provided early evidence on the importance of current wealth for the housing demand of first-time owners. Engelhardt (1996a) confirmed that household consumption increases after a household enters homeownership. Boehm (1993), Sheiner (1995) and Jones (1995a) showed that would-be owners accumulate wealth so as to be able to meet the down-payment constraint.

The down-payment constraint is now generally regarded as an important aspect of housing demand, and plays a prominent role in recent analyses of the functioning of housing markets. See Stein (1995), for instance, and the associated empirical work in Lamont and Stein (1999) and Ortalo-Magné and Rady (2006).

\subsection{Mortgage Insurance and the Mortgage Qualification Constraint}

The apparent tightness of the down-payment constraint for many young households suggests that a substantial welfare gain can be reached through mitigating or removing this constraint. In the Netherlands, this was attempted by a mortgage insurance facility known as National Mortgage Guarantee (National Hypotheek Garantie, abbreviated in Dutch as NHG). This insurance protects the lender against default risk, as the insurer guarantees repayment of the loan in case the homeowner fails to pay. The NHG was introduced by the government with the explicit purpose of lowering the threshold for homeownership experienced by low-income households, and appears to be highly successful in reaching that goal. With the NHG insurance, a borrower is able to finance $100 \%$ of the purchase price of a home and even the transaction costs with the mortgage loan. Because of the lower risk, banks charge a somewhat lower mortgage interest rate for loans that are insured in this way. This makes the NHG quite popular among all qualified homeowners, which apparently solves the adverse-selection problems one could otherwise expect to be present. ${ }^{20}$

20 Qualification is limited by a maximum size of the loans that can be insured through the National Mortgage Guarantee, and by a mortgage qualification constraint to be discussed 
The NHG does not allow unlimited borrowing by households, however. To keep the risks within manageable proportions, the NHG is willing to provide insurance only if the ratio of mortgage payments to income of the homeowner does not exceed a limit set by the NHG. Effectively, the presence of this limit implies that the down-payment constraint is replaced by another constraint, which we will call a mortgage-qualification $(m-q)$ constraint.

This does not imply that the NHG is an ineffective instrument: it mitigates the necessity for accumulating wealth before entering homeownership and therefore lowers the threshold. The mortgage-qualification constraint puts a maximum on the price a household is able to pay for a house, and this maximum is related to the household's current income. Particularly for households that expect future income growth (and it appears from Figure 2 that many homebuyers have reason to do so) this condition implies a threshold for entering the market for owner-occupied homes. These households will still find it useful to accumulate wealth before purchasing a house, since it allows them to adjust housing consumption better to lifetime resources. This behavior makes it possible for households to avoid high moving costs associated with later adjustment of owner-occupied housing. The m-q constraint may therefore have similar effects on homeownership and saving behavior among households in the early stages of the life cycle as the down-payment constraint. Alessie and Kapteyn (2002) and Rouwendal and Alessie (2003) present some empirical evidence of its effects.

It should be noted that a mortgage-qualification constraint like the one used by the Dutch NHG is not completely unknown in other countries. Although the down-payment constraint is usually regarded as the tightest restriction, banks tend to keep an eye also on the ratio of mortgage payments to income, which probably indicates default risk associated with reductions in income. It may therefore be argued that the NHG successfully removes the down-payment constraint, and that the $\mathrm{m}-\mathrm{q}$ constraint consequently receives more attention.

Intertemporal utility maximization suggests that households relate their housing consumption (adjusted for household size) to lifetime resources, whereas the mortgage-qualification constraint relates housing consumption to current income. The $\mathrm{m}-\mathrm{q}$ constraint is hard to remove through insurance, since income risk is generally regarded as uninsurable. There are, however, other possible responses to its presence.

Footnote 20 continued

below. In practice, the benefits of the reduced interest payments exceed the costs of the insurance, which makes the insurance attractive to many households. This suggests, of course, that either the insurance premium is too low, or that the discount on the mortgage interest rate is too large (in the sense of being actuarially unfair). Since the insurer reports to make a profit year after year, the first possibility seems to be excluded. It appears therefore that the Dutch mortgage market is not fully competitive. 


\subsection{The Down-Payment Constraint and Mortgage Design}

A homeowner can meet a down-payment qualification constraint only by investing a sufficient amount of wealth in the house. A mortgage-qualification constraint, however, can be relieved also by choosing a particular mortgage type. The reason for this is that the $\mathrm{m}-\mathrm{q}$ constraint considers the ratio of mortgage payments to income only at the time the mortgage is taken. Mortgage-interest deductibility clearly provides substantial help in meeting this constraint ${ }^{21}$ through its effect on net interest payment. The interest rate itself must, of course, be taken as given by households.

Mortgage-interest payments usually consist of interest payments and other outlays that ensure that the loan will be paid back in due time. In the case of linear and annuity mortgages, these are direct repayments. With respect to life insurance and other endowment mortgages, these are investments in a life insurance policy or assets, which are ultimately used to repay the loan. The choice of the mortgage type affects the size of these payments in the first year substantially. In general a longer mortgage amortization term decreases the size of these other payments, and with a linear mortgage, first-period payments are much higher than with the other types. An interest-only mortgage reduces the compulsory other payments to zero. In some circumstances, banks are even willing to accept partial payment of mortgage interest in the first period, while adding the remaining part to the outstanding loan. Although the latter arrangement is exceptional, ${ }^{22}$ the introduction of new mortgage types in the Netherlands since the 1980s has shown a consistent move towards lower initial payments (see Rouwendal (2007b)).

\subsection{Effects of Housing on Labor Supply}

The mortgage-payments-to-income ratio can be decreased not only by lowering mortgage payments, but also by increasing income. Female labor supply may be particularly responsive to the presence of a mortgage-qualification constraint. This possibility was investigated by Fortin (1995), who studied household labor-supply decisions conditional on the value of the home owned and the mortgage debt assumed. ${ }^{23}$ She concluded that mortgage commitments are significantly related to the labor-market decisions of married women.

21 This is at a given level of house prices. Note that it is not impossible that the house-price level itself depends on the presence of mortgage-interest deductibility.

22 In the Netherlands the so-called 'growth mortgage' characterized by partial interest payments and a growing size of the loan was introduced in the 1970s when house prices increased rapidly. Its popularity plummeted after the collapse of the housing market in the early 1980s. More recently, such growth mortgage loans seem to have gained popularity in the US.

23 Fortin (1995, p. 551). 
Other studies ${ }^{24}$ have confirmed the presence of a clear relationship between homeownership and labor supply. This relationship is also apparent from Figures 3 and 4 of the previous section, which show that two-earner households are much more common among owners than among renters, and that the number of hours worked by the adult members of owner-occupied households is almost twice that of the adult members of renting households. Moreover, house prices in the Netherlands (especially in the western part) are currently so high that only two-earner households can afford to buy a decent home. This confirms Fortin's finding that female labor-force participation rates are close to $100 \%$ for households whose debt-service ratio would otherwise approach (or exceed) the allowable limit (Fortin (1995, p. 551)).

These observations, while suggestive, are not conclusive. Labor supply and housing demand should be regarded primarily as simultaneous decisions. If household preferences are separable in labor supply (leisure) and consumption, it is possible to study labor supply and housing demand in relative isolation: that is, by conditioning only on (full) income. If this assumption is satisfied, and there still would be an effect of housing consumption on labor supply, this could reasonably be interpreted as the effect of a constraint on behavior associated with housing. This separability assumption, however, is typically rejected (see Browning and Meghir (1991) for a general analysis and Aldershof et al. (1996) for a study that focuses on housing). In the absence of separability, finding a significant positive coefficient for housing consumption in a labor-supply equation does not constitute proof of an effect of credit restrictions (like the mortgage-qualification constraint) on labor supply. Unless further evidence is present, an alternative and equally plausible explanation is that households with strong preferences for housing tend to be households that supply more labor. This simultaneity complicates all attempts to establish a causal link between $\mathrm{m}-\mathrm{q}$ constraints and labor supply.

For instance, it is probable that in the Netherlands the combination of increasing female labor-force participation in the 1990s and inelastic housing supply (see Vermeulen and Rouwendal (2007)) has contributed substantially to increasing house prices. In this case, the causality runs primarily from the labor market to the housing market, instead of the other way around. But, to complicate matters, the increase in female labor supply in the 1990s may partly have been caused by a changing mortgage-qualification constraint. Before the 1990s, lenders computing the mortgage-payment-to-income ratio took into account the income of only the main earner; since then, it has

24 They include Ioannides (1988), who wrestled with the estimation problems associated with the quasi fixed character of housing during residential spells and the borrowing constraint, Kohlhase (1986), who stressed the interdependence of both decisions, and Phillips and Vanderhoff (1991), who focused on the housing-market impact of women's choices for professional and managerial jobs. 
become common also to include the income of a second earner. This change in the relevant constraint may have induced women to accept a job in order to be able to buy a better house.

More recent studies of the relationship between labor supply and housing demand have attempted to take this simultaneity into account. For instance, Del Boca and Lusardi (2003) use institutional shifts in the Italian credit market to identify an effect of mortgage usage on labor supply. The change concerned a shift from a down-payment constraint to a type of mortgagequalification constraint that resulted in a marked increase in the number of mortgage loans and their average size. These developments coincided with a substantial increase in female labor-force participation. Although the model used by Del Boca and Lusardi allows for simultaneity, the authors found that it is recursive, especially for younger households, and that causality runs from the housing market to the labor market. ${ }^{25}$

This analysis suggests that a transition from a system with a downpayment constraint to one with a mortgage-qualification constraint results in an increase in female labor-force participation over at least the period in which mortgage payments put heavy pressure on the household budget, and not just around the period at which a house is bought and the constraint has to be met. The removal of the down-payment constraint changed the environment in which the simultaneous decision making about housing demand and labor supply takes place, and this resulted in an increase in both.

It is also conceivable (and in the light of the previous discussion somewhat probable) that after the mortgage loan has been repaid, labor supply will decrease. The more traditional (linear and annuity) mortgage loans, which were quite popular (at least in the Netherlands) until the 1980s, imply the forced accumulation of wealth in the house. The combination of the absence of further mortgage payments and the presence of a considerable amount of home equity probably discourages labor supply in later stages of the life cycle. Note, however, that the a priori evidence for such an effect is not strong: Figures 3 and 4 of the previous section show that labor supply among homeowners is larger than that among renters, also in later stages of the life cycle. It must be taken into account, however, that renters and owners tend to differ in many more aspects than just the aspect of homeownership. Doling and Horsewood (2003) present suggestive evidence that owner-occupiers - especially when they are outright owners - indeed tend to reduce their labor supply. This is confirmed by the in-depth analysis of Bloemen (2007),

25 Other recent studies include Bottazzi (2004), who finds smaller effects on participation than Fortin (1995), and provisional exercises reported in an unfinished working paper of Attanasio et al. (2005b), which suggest that the labor-market effects of mortgage borrowing constraints are small. 
who finds a significant positive effect of housing wealth on the job exit rate to early retirement and a significant negative effect of mortgage debt.

\subsection{Demand for Mortgage Loans}

Apart from the down-payment constraint, a second important feature of AV's analysis is that the house is treated as a completely illiquid asset. Throughout the period it owns the house, the household makes fixed mortgage payments and therefore accumulates wealth in the house. AV allow the household simultaneously to save from labor income at the same interest rate. Given their assumption that the only asset available to a household is a savings account with an interest rate equal to that paid on the mortgage, this raises no further questions. However, it was pointed out by Brueckner (1994) and Jones $(1993)^{26}$ that holding such a savings account might be suboptimal for a household if the mortgage interest rate differs from that of the savings account - or that of any other asset in which a household may want to invest. Such differences in rates of return may be associated with capital market imperfections and, probably more importantly, with fiscal measures. It is not difficult to show that it is not optimal not to repay the mortgage if the interest rate on any other asset (after correction for the risk involved) is higher than that on the mortgage, whereas it is optimal to repay as soon as possible in the reverse case - unless the household wants to borrow for purposes other than housing. In the Canadian situation to which Jones refers, mortgages are frequently refinanced (often every 5 years), implying that households can adjust the outstanding loan to their actual situation, which differs from the assumptions of the AV model. Jones (1993, 1995b) showed that in many cases the actual outstanding amount of the mortgage loans is larger than needed for housing purposes, which suggests that mortgage loans are used to finance non-housing portfolio objectives.

The Canadian practice of frequent refinancing of mortgage loans also suggests that AV's assumption of the complete illiquidity of the capital invested in the house is not always a realistic one. This is also true in other countries, like the Netherlands. For instance, although in the Netherlands it is unusual to refinance mortgage loans frequently, moving to another house implies renegotiation of the mortgage and often extending the size of the loan, possibly by taking a second mortgage. A second mortgage may also be taken without moving. Unlimited mortgage-interest deductibility often makes it unattractive to repay the loan, since investing in other assets is likely to

26 Jones used the model presented in Ranney (1981) as the organizational framework for his analysis. This model deals with homeowners only and has the size of the mortgage as an endogenous variable. Jones introduced into this model a difference between the (net) interest rate on mortgages and the (net) returns on the asset in which the household can save. 
offer higher returns. Especially since the tax reform of 2001 lowered the effective tax rates on capital returns, it is almost always in the interest of the homeowner to maximize mortgage debt (see Rouwendal (2007a)). In a situation with constant house prices (which was assumed by AV), this would imply that households prefer not to accumulate wealth in housing, and may prefer to take an interest-only mortgage. The actual situation in the Netherlands is different, since house prices have risen considerably, especially in the 1990s, and households often have considerable amounts of home equity, even if they choose not to repay their mortgage or take a second or third one, as was documented in Figure 11.

Innovations on the mortgage market did not occur only in the Netherlands. A recent analysis by Gerardi et al. (2007) shows that deregulation and innovation in this market have also been of importance in the US, and argues that this has benefited many households. Information about countries other than the US may be found in Green and Wachter (2005). It is clear, therefore, that AV's assumption that housing is a completely illiquid asset is to say the least - somewhat stronger than reality suggests. ${ }^{27}$ The increased flexibility in mortgage choice and repayment behavior is in all probability welfare-increasing. Piskorski and Tchistyi (2006) suggest that the combination of an interest-only mortgage with a flexible home-equity line of credit is optimal. $^{28}$

\subsection{Housing Demand of Elderly Households}

The stylized pattern of housing-tenure choice over the life cycle suggested by AV was in broad agreement with the empirical pattern in many countries in the 1970s and even that of today, as Figure 1 above shows. These days, however, the decline in homeownership occurs much later than it did 30 years ago, and sizable cohort effects makes the figure, which is based on a single crosssection, less representative of longitudinal developments than appears to be the case at first sight. These cohort effects are also reflected in Figure 8 (referring to the elapsed duration of stay) and Figure 9 (referring to mobility). Indeed, the latter figure shows a prolonged decrease of mobility rates among ageing owner-occupiers, whereas AV's analysis suggests increasing mobility around the time at which households want to start consuming their housing wealth.

Better insight in these cohort effects is obtained by following 5 year birth cohorts through a series of Housing Needs Surveys. The result of such an analysis is shown in Figure 13 which shows the development of

27 The development of adjustable rate mortgages will be discussed in the next section.

28 This conclusion is reached in a model with income uncertainty and asymmetric information. An alternative optimal mortgage contract is an optional adjustable rate mortgage. 


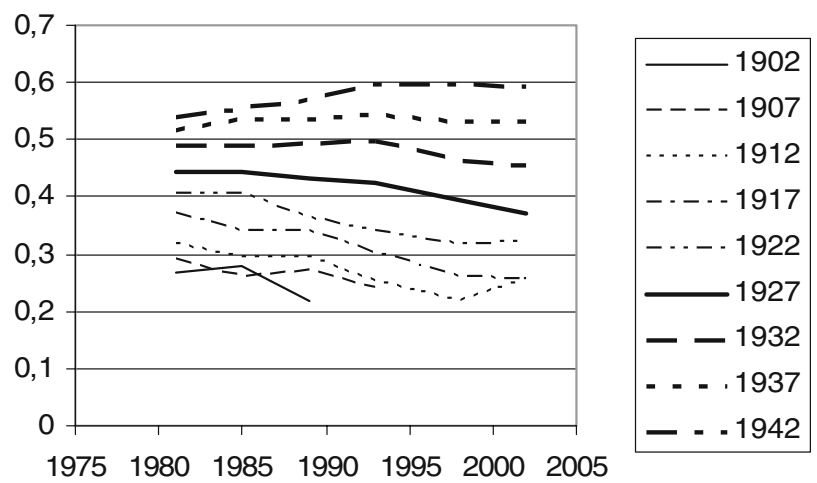

Figure 13 - Development of home ownership rates of cohorts born between 1900 and 1944. The lines in the figure show average homeownership rates of households whose head is born in the years 1900-1904, 1905-1909,... in the housing needs surveys of 1981, 1985, 1989, 1993, 1998 and 2002. Source: own computations based on WBO

homeownership among 5 year birth cohorts over the period 1981-2002. For instance, the solid line refers to households whose head was born between 1925 and 1929 and therefore reached the age of 65 between 1990 and 1994. This line decreases somewhat, but much less than the cross section line in Figure 1. A similar observation holds for the other cohorts. It must therefore be concluded that there is only a modest decrease in homeownership when households age.

In line with this evidence, empirical research has consistently shown that elderly households are much more reluctant to leave their owner-occupied home than was suggested by AV's analysis - even if this implies that a considerable amount of equity is not used for consumption purposes. For instance, Venti and Wise (1990) draw the following conclusion:

Most elderly are not liquidity constrained. And, contrary to standard formulations of the life-cycle hypothesis, the typical elderly family has no desire to reduce housing equity. This is true even among families with low total wealth for whom housing equity is a large fraction of their total wealth. (Venti and Wise (1990, p. 26))

Although this conclusion has generated some debate, with later contributions including Hurd (1999a, b,c) and Megbolugbe et al. (1997), Venti and Wise (2000) draw essentially the same conclusion when reviewing the literature 10 years later. Moves from owning to renting are usually associated with deteriorating health or death of a spouse, and often have little to do with a desire to free resources for general consumption purposes. Venti and Wise present evidence that the share of people who intend to stay in their current 
house as long as possible is increasing in age and is higher than $95 \%$ for those at least 75 years of age.

The conclusion that most of the elderly are not credit-constrained is somewhat puzzling, given the substantial amount of wealth they have usually accumulated in their house. Life-cycle consumers who prepare to die with zero wealth should be eager to consume it, before it's too late. However, there are some obvious potential explanations for this behavior. It seems reasonable that many households - especially those with children, but also others would like to bequeath some wealth. This was investigated by Hurd (1999c), who concluded that although there is some evidence for such a motive, it is not particularly strong. He suggests that most of the actual bequests are unintended. Ameriks et al. (2007) found a stronger role of bequest motives. A second potential explanation for the large wealth holdings of the elderly is the precautionary motive associated with health and mortality risks. We return to this in the next section. A third explanation is provided by psychological theories that stress that 'as people age and increasingly perceive time as finite, they attach less importance to goals expand their horizons and greater importance to goals from which they derive emotional meaning' (Carstensen (2006, p. 1914)). This could explain why people prefer to stay in their present home, even though moving to a smaller house would better fit their housing needs and free resources for other consumption purposes (Fisher et al. (2007)).

Although the literature stresses the unwillingness of most elderly households to reduce their home equity, there may nevertheless be a sizeable group of such households that would prefer to consume at least some of their housing wealth if they would only know how to do so. In this connection, one might think of households with only a small pension income, who are outright owners of a house they bought decades ago. Such households may own a sizable amount of home equity that could be used to increase their welfare through a reverse mortgage loan. Although such mortgage loans have been developed and introduced, demand seems to be virtually absent. While this may have to do with the fact that many households do not like to decrease their home equity, it may just as well indicate that many households that are potentially interested in such a loan do not have the relevant information or financial literacy to be able to realize their wishes. ${ }^{29}$

\subsection{Conclusions}

Most of the literature that has been reviewed in this section stresses the distortionary effects of borrowing constraints on household behavior. It is

29 See Caplin (2000) for a discussion of the slow or lagging introduction of seemingly straightforward product innovations, like reverse mortgages, on the housing finance market. 
therefore useful to note in this concluding subsection that these constraints also play - at least potentially - an important beneficial role: they protect both the lender and the borrower against the risks (and associated costs) of default. Although it may be argued that the constraints are brute-force measures that may in many cases be unnecessarily restrictive, the fact that they prevent forced movements of households that have assumed too large a mortgage loan (only to discover that they are unable to pay for it) should be counted as a substantial benefit associated with their presence. This is not to say that we should not try to refine these constraints: the introduction of the NHG in the Dutch context is a major example of the development of a policy instrument that substantially improves the functioning of the housing market, without allowing too much room for risky loans. The Dutch experience in the beginning of the 1980s, as well as current experiences in the US, suggests that in the absence of appropriate borrowing restrictions households and banks agree upon loans that turn out to be too risky when the general economic environment deteriorates.

\section{RISK AND HOUSING}

This section explores the effects of risk on the demand for housing and other assets. We discuss six topics. The first is that homeownership is fundamentally a protection against risk. In an uncertain world it generates a steady flow of housing services as long as the household remains in the house. It is important to start with this rather elementary observation, which was often overlooked in earlier analyses of homeownership. The second topic is house-price risk, and the third the optimal asset portfolio of homeowners - an issue that has usually been considered in the context of mean-variance analysis. Fourth, we focus on the choice between fixed- and adjustable rate mortgages. We then discuss the effect of income risk and its connection with housing. Finally, we consider health and mortality risks.

\section{1 'My Home is My Castle'}

It is important to start with the observation that homeownership protects against risk. Property is protected by law. A homeowner has more freedom and independence than a renter has - and he also has more certainty.

Campbell and Viceira (2002, Chapter 3) stressed that for a long-term investor consols (that is, bonds that offer one unit of real income per period) are the relevant riskless asset. The owner-occupied house offers a constant flow of housing services after it has been purchased, and can therefore be interpreted as a consol that refers to one specific commodity. Investing in this commodity protects the household against all kinds of variations in economic circumstances that would otherwise cause fluctuations in the demand for 
housing services. Sinai and Souleles (2005) stress one important aspect: that owner-occupied housing is a hedge against rent risk. Although this aspect is clearly more relevant to the US - to which their empirical analysis refers there has recently also been some discussion in the Netherlands about the relaxation of rent control. ${ }^{30}$

\subsection{House Prices and House-Price Risk}

House prices can change considerably over time in ways that are not always easy to understand. ${ }^{31}$ Explanations vary between market theories (in which house prices are determined by construction costs and the opportunity cost of land) and the random-walk hypothesis. It is somewhat paradoxical that both extremes rely very heavily on the unrestricted operation of market forces, and it should also be noted that many prominent observers of the housing market have suggested that price movements cannot be fully understood as a result of the actions of rational actors.

It is by now a well-established fact that house prices do not follow a random walk. This was first noticed by Case and Shiller (1989), who estimated an autoregressive parameter equal to $0.25-0.50$. Clearly this, in itself, does not prove that actors on the housing market behave irrationally. For instance, Poterba (1984) showed that capacity restrictions in the construction industry make the short-run supply curve for housing upward sloping, and that this results in a predictable adjustment path for house prices in a model where homeowners have rational expectations.

On the other hand, it is clear that housing supply does not react fast enough to price movements to keep house prices close to the sum of construction costs and the opportunity cost of land (see, for instance, DiPasquale and Wheaton (1994), Mayer and Somerville (2000)). Indeed, recent analyses have stressed the role of natural and manmade (spatial planning) restrictions on house prices (see, for instance, Gyourko et al. (2006)). Such restrictions imply that demand indicators, notably income and mortgage-interest rates, are important predictors of house prices.

Currently, it is well accepted that house prices are autocorrelated and mean-reverting, and that economic models should take this into account. For instance, Glaeser and Gyourko (2007, p. 1) report that 'a $1 \$$ increase in real house prices in one year is associated with a 71 cent increase in the next year. A $1 \$$ increase in local market prices over the past five years is associated with a 32 cent decrease over the next five-year period.' The state-of-the-art

30 It may also be noted that in the 1990s real rents increased for a number of years, notwithstanding the huge rental protections granted in the social rental sector in the Netherlands. 31 See, for instance, the evidence presented in Quigley (2006) for a number of European countries. 
practice in modeling house prices is to estimate an error-correction model with a structural long-term relationship (in which income usually plays a prominent role) and a partial adjustment process that causes short-run autoregression (see, among others, Abraham and Hendershott (1996), Malpezzi (1999), Capozza et al. (2004)). The implication is that house prices are in the long run strongly dependent on income: that is, on the returns to human capital.

If the demand for housing should indeed be regarded primarily from a long-term investor's perspective, then the effect of price uncertainty is much smaller than would be suggested by a one-period analysis. The long-term perspective, however, is not relevant for everyone. Especially for would-be homeowners who are saving for the down payment, short-term fluctuations in house prices can imply significant changes in the constraints they face. This was recently stressed by Banks et al. (2004), who argued that price uncertainty provides an incentive to enter the owner-occupied market as early as possible, since fluctuations in the presently owned house act as insurance against changes in the price of the next house.

\subsection{Mean Variance Analysis}

The standard framework for analyzing short-run investment behavior is mean-variance analysis, and it is possible, albeit somewhat unusual, to incorporate housing as an asset in this framework. For instance, Goetzmann (1993) observed that housing (real estate) has a low or negative correlation with other assets (stocks, bonds), and would therefore in principle be a valuable addition to an investor's portfolio - a conclusion that was confirmed in later work by Englund et al. (2002), Iacoviello and Ortalo-Magné (2003) and Quigley (2006). However, Brueckner (1997) pointed out that introduction of the owner-occupied house into the investment portfolio should account for the double role of housing as an asset as well as consumption good. As first noted by Henderson and Ioannides (1983), this implies that the amount of money invested in housing as an asset must be at least as large as the amount invested in housing for consumption purposes. This imposes a constraint on portfolio choice behavior. Flavin and Yamashita (2002) used a slightly different model in which a mortgage loan (that cannot exceed the value of the house) was introduced as an additional asset. This model implies a strong relationship between the ratio of housing to net worth and the composition of the optimal portfolio. ${ }^{32}$ A lower value of the ratio implies a higher share of stocks, although the exact values depend on the degree of risk aversion.

$32 \mathrm{Hu}$ (2005) derived a similar prediction, developing a model that also explains tenure choice over the life cycle. 
Flavin and Yamashita (2002) reported empirical evidence confirming the shift of household portfolios towards stocks over time, which is consistent with their model. Later empirical work has been less favorable, however, regarding the usefulness of the constrained mean-variance model as a descriptive device (see Yamashita (2003), Pelizzon and Weber (2006a, b)). This implies that many households do not realize the gains that would be possible if they were to adjust their portfolio optimally to their owner-occupied house (see Englund et al. (2002) for computations of the gains conditional on housing consumption).

One possible reason for the relatively poor performance of the mean-variance model is that the literature discussed above ignores labor-income risk (see Cocco (2005)); another is that this model provides essentially a period-toperiod analysis, whereas housing must be regarded as a long-term investment, as has been stressed by Campbell and Viceira (2002).

\subsection{Adjustable or Fixed-Rate Mortgages?}

Our discussion of mortgage-market innovation in the previous section ignored one important development - that of adjustable rate mortgages, which is essentially related to risk. The adjustable rate mortgage loan (ARM) was introduced in the early 1980s. The most obvious difference between a fixedrate mortgage (FRM) and an ARM is that the interest rate at which the former is offered is higher. This means that the ARM offers a household the possibility to soften the mortgage-qualification constraint, although this benefit brings with it the risk of a higher interest rate in later years. Early analyses of ARMs (see, among others, Brueckner and Follain (1988, 1989)) have confirmed that the demand for this type of mortgage depends strongly on the difference between the FRM and ARM rates, and that ARMs tend to increase the demand for housing.

In their extensive analysis of the choice between ARMs and FRMs, Campbell and Cocco (2003) found large welfare effects associated with different mortgage types. ${ }^{33}$ Although these authors did not carry out an empirical analysis, they suggested that optimal outcomes of their calibrated model correspond well with empirical evidence reported by Shilling et al. (1987). Koijen et al. (2007) developed a much simpler model of mortgage-type choice and found that the main prediction of their model, that time variation in the bond risk premium is an important determinant of the choice between an FRM and an ARM, is confirmed by the data.

Campbell and Cocco (2003) also showed that an inflation-indexed FRM avoids the risk of varying monthly mortgage payments associated with ARMs 
and the wealth risk associated with an FRM. They also discussed possible reasons for the absence of such a mortgage type in actual markets.

\subsection{Labor-Income Risks}

Almost all studies on the relationship between housing and portfolio choice ignore income risk, although this is presumably an important explanatory variable. Incorporating income uncertainty in life-cycle models of consumption and savings has substantial consequences for the predictions that can be derived from these models. For instance, the precautionary savings motive tends to become much more important once income uncertainty is taken into account. Introducing such income uncertainty in a model of the type studied by AV may well make households reluctant to switch to illiquid owner-occupied housing unless a buffer stock of accumulated savings remains. Uncertainty with respect to future incomes has effects that are often similar to, but not in all respects identical with, those of borrowing or other constraints. It has indeed been found that labor-income uncertainty is also important for homeownership (Diaz-Serrano (2005)) and, more specifically, that households whose incomes co-vary with housing prices are more reluctant to enter homeownership (Davidoff (2006)). ${ }^{34}$ We noted above that the currently popular housing-price models suggest that there is a strong relationship between regional or metropolitan income and house prices. This suggests that laborincome risk and house-price risk are strongly correlated, and this relationship should be expected to have - potentially significant - consequences for the attractiveness of homeownership.

\subsection{Mortality and Health Risks}

In the previous section we noted that the incorporation of health and mortality risks into the analysis could explain the relatively large amounts of wealth, including housing wealth, garnered by the elderly. ${ }^{35}$ Indeed, the observation of a strong reluctance to decrease housing equity tends to disregard such catastrophic events as the death of a partner or serious illness. Although it was observed that even in case of the death of a partner (or his or her move to a nursing home), the remaining partner tended as a rule to continue in the existing housing situation, it may nevertheless be the case that precautionary motives associated with such events provide an explanation for the

34 Attanasio et al. (2005b) reported, in line with our discussion in Section 3.5, that female labor supply can provide partial insurance against idiosyncratic risk, especially when credit constraints are present.

35 Engelhardt (2008) recently argued that the high homeownership rates among elderly Americans are strongly related to the presence of social security, which diminished the need to sell the house to consume the equity. 
substantial wealth holdings of elderly households. ${ }^{36}$ Palumbo (1999) showed that a life-cycle model that incorporates uncertain medical expenses could indeed explain a substantial part of the gap between optimal (according to the theory) and actually observed saving behavior of elderly households. Hurd (1999a, b, c) stressed the importance of the consequences of the death of a spouse for the income flow of the surviving partner, and its implications for the value attached to wealth holdings. He concluded that much of the discrepancy between life-cycle theory and observed behavior disappears, once this is taken into account. The important message seems to be that wealth holdings of the elderly can be understood only if health and mortality risks are included in the analysis, or as Coile and Milligan (2006) put it in a recent empirical study: 'factors other than the standard risk and return considerations may weigh heavily in many older households' portfolio decisions' (p. 23). ${ }^{37}$ More suggestive evidence is provided in Ameriks et al. (2007). For the Dutch situation, recent research by Haffner (2005) confirmed that Dutch households consider home equity more as a resource to be used in case of 'catastrophic events' than as a source of regular supplementary income. ${ }^{38}$

It should be noted that, if these suggestions are true, they not only explain the reluctance of most elderly households to reduce their home equity under normal circumstances, but also highlight the demand for flexible arrangements in case of catastrophic events. If households would like to have the possibility to take up some of their home equity in liquid form, they should make arrangements before such events occur. It is therefore desirable to have opened a flexible credit line that offers the possibility to borrow money with the house as collateral before such an event happens, in order to be able to use it when necessary.

\subsection{Concluding Remarks}

It is somewhat surprising that the literature (to my knowledge) is almost silent on the significance of interest-rate risk for homeowners, although it can easily be argued that this is the most important type of risk they bear. For many homeowners, mortgage-interest payments are a sizable part of their monthly expenditure, and an increase in the mortgage-interest rate of $1 \%$ point (from $5 \%$ to $6 \%$, say) implies an increase in these payments of $10 \%$

36 It is possible in principle to insure against some of these risks. For instance, in the Netherlands it is common practice to offer a life insurance when buying a mortgage.

37 See also Heiss et al. (2003) for suggestive evidence on the development of health, wealth and living arrangements at the end of the life cycle. They showed that wealth and health are strongly related to each other. Wealthier persons live longer and are healthy longer. For the initially wealthy, living with others decreases the expected future wealth relative to living alone - an effect that is probably due to intra-family transfers.

38 See also SCP (2004). 
or more. Many homeowners protect themselves against this type of risk by assuming an FRM, but there are other ways in which the interest rate affects the housing market. Rising interest rates have immediately negative implications for the ability of would-be owners to buy a house when a mortgagequalification constraint is present. An increase in the interest rate therefore tends to depress the demand for housing, and this may have substantial consequences for house prices. For households with high loan-to-value ratios, decreasing house prices signal increasing default risk to the lender, who may wish to renegotiate the loan. Finally, a rising interest rate often coincides with a downturn in general economic prospects, thereby increasing the pressure on house prices and dampening expectations with respect to future income developments. Thus, interest-rate risk, house-price risk and income risk appear to be correlated - and since all three have significant implications for housing demand, this further suggests that it may be worthwhile to pay more attention to interest-rate risk. ${ }^{39}$ One additional consideration that reinforces this suggestion is that the tax deductibility of paid mortgage interest decreases the income tax base. An increase in the mortgage-interest rate may have a substantial effect on income tax revenues and therefore on the state of public finance. In the event that such an increase coincides with a recession, the government may be compelled to take restrictive measures with negative effects on employment, income, and so forth.

\section{OWNER-OCCUPIED HOUSING IN A LIFE-CYCLE PERSPECTIVE}

\subsection{Housing Consumption, Transaction Costs and Habit Formation}

The previous sections suggest that owner-occupied housing is valued highly by most households as a durable consumption good. Many households want to buy a house as soon as their household situation has stabilized, and once they enter the owner-occupied sector, they are reluctant to return to the rental sector. Households with children are often owner-occupiers, and once they enter the empty-nest phase, these households tend to stay in their house. Even when they reach an advanced age and their health deteriorates, most households intend to stay in the house in which they usually have already been living for many years. The very high elapsed durations of stay of elderly owner-occupiers are suggestive of a strong reluctance to move to another house (to any other house) among this group of households.

From the point of view of economic analysis, this inertia in housing consumption can to some extent be interpreted as a confirmation of the basic life-cycle hypothesis. Households adjust housing consumption to their lifetime

39 Jackman and Sutton (1982) analyzed changes in the interest rate in an economy where an illiquid asset (a house) can be financed through a (mortgage) loan. 
resources on the basis of their own idiosyncratic preferences, and unless unexpected events (such as a divorce or the death of spouse) necessitate a change, they see little reason for adjustment. The life-cycle interpretation of housing demand restricted by borrowing constraints appears to be particularly convincing in the first stages of the life cycle - when many households experience difficulties in entering the owner-occupied sector and are willing to accept high mortgage payments to reach that goal, while being eager to find the type of mortgage that fits them best.

However, this is less clear for later stages of the life cycle. Intertemporal utility maximization suggests that 'empty-nest' households reduce their housing consumption according to the decreased need for space associated with a smaller household size and, in the process, free some of the equity accumulated in their home for consumption purposes. In reality, households are clearly unwilling to do the former. Even when they reach a more advanced age, and health conditions presumably increase the burden of living in a large house (often with a garden), most owner-occupiers are unwilling to give up their residence. Although the small size of the rental sector for middle or upper middle class in the Netherlands may provide part of the explanation, ${ }^{40}$ it seems probable that a considerable amount of habit formation - becoming accustomed to the house in which one has lived for such a long time and its social and physical environment - is involved.

Associated with this are the high transaction costs associated with moving to another house. The monetary costs associated with realizing such a move are certainly high. ${ }^{41}$ But the literature, reviewed in Quigley (2002), suggests that psychological and social costs are of crucial importance. This is not to say that such behavior is necessarily irrational. ${ }^{42}$ Although one may agree with Clark and Deurloo (2006) that it is remarkable that most Dutch households currently live in spacious dwellings (whereas there was significant concern about the provision of adequate housing only 25 years ago), the available evidence suggests strongly that this high level of housing consumption agrees with their preferences. It is therefore doubtful whether policies aimed at the reduction of housing consumption of elderly owner-occupiers would be welfare-improving.

40 The Netherlands has a large social rented sector, but entrance is restricted to those with low incomes and/or urgent housing needs.

41 Grossman and Laroque (1990) provided an important contribution to the analysis of intertemporal utility-maximizing behavior under uncertainty in the presence of transaction costs. Recent analyses of housing demand with transaction costs include Martin (2003), Flavin and Nakagawa (2004) and Chetty and Szeidl (2007).

42 It may certainly be irrational. For instance, the low out-of-pocket housing costs of outright owners might give them the impression that they live quite cheaply, thereby leading them to overlook the considerable opportunity cost of home equity. 
The evidence that these households are also intentionally keeping so much of their wealth illiquid as equity accumulated in their house is, in my view, less convincing. The priority of elderly owner-occupiers clearly seems to be to stay in the house in which they currently live for as long as possible. Any financial arrangement that would violate this priority probably has little chance of being acceptable to these homeowners. This does not imply, however, that such households are unwilling to use their equity for consumption or health expenditure purposes - should they feel the need for such purchases and feel that the arrangements under which they are made possible fitted them well. Reverse mortgages and flexible lines of credit based on housing collateral should probably be given a second chance. One argument in favor of this opinion is the effect of an increase in the house price on household consumption, to which we now turn our attention.

\subsection{House Prices and Consumption}

The fact that households see their dwelling primarily as the source of a steady flow of housing services does not imply that they are insensitive to the effect of changes in its value. The analysis of AV suggests that the value of the house is important only at the time the house is sold and the household returns to the rental sector. In a more general model in which the household is able to downgrade or upgrade housing consumption, losses or gains could also occur during a household's sojourn in the owner-occupied sector.

Even if a household does not move, information about fluctuations in house prices in general will tell them that their own wealth position has changed, and this might affect their consumption decisions. There is indeed some evidence that house prices significantly affect household consumption. The point that this is potentially a significant effect was made forcefully by Muellbauer and Murphy (1990), who argued that financial liberalization would lead to rising house prices and a stronger reaction of consumption to such changes. Their analysis, however, has not been generally accepted.

A difficulty that arises when looking empirically for the effect of changes in house prices on consumption is that increases in house prices are often related to positive shocks in the economy. Such shocks affect expectations with respect to future incomes and therefore consumption expenditure. Housing is one element of consumption demand, and since housing supply is inelastic, at least in the short run, an increase in the housing price is likely. This increase may have an additional effect on consumption expenditure, but it will be hard to distinguish from the general effect of improved economic conditions, and is therefore difficult to isolate. A study by Attanasio and Weber (1994) based on micro data ${ }^{43}$ attempts to isolate this affect, and finds 
moderate effects of house-price changes. More recently, Campbell and Cocco (2006) reported more substantial effects. ${ }^{44}$

A fundamental objection to the idea that changes in house prices will have significantly positive effects on aggregate consumption is that the 'gain' for the seller equals the 'loss' for the buyer. These two effects counteract each other, and one would generally expect that the net result would be close to zero (Skinner (1989); see also Bajari et al. (2005)). However, this does not exclude the possibility that substantial effects for individual consumers are present, or that the average effect is non-zero. Unrealized capital gains can have consumption effects if homeowners are not credit-constrained, and these effects may be particularly relevant for elderly homeowners. For credit-constrained (younger) homeowners, higher house prices may imply the possibility to borrow against their emerging home equity. On the other hand, the 'buyers' are the future homebuyers, who may not realize their loss unless they already were actively saving to buy a house.

A sequence of papers has argued for the presence of substantial effects of house prices on consumption. ${ }^{45}$ Engelhardt (1996b) stressed that, according to the life-cycle hypothesis, only unexpected increases in house prices should affect consumption. He attempted to distinguish expected house-price changes from unexpected ones. In his empirical work he found a substantially larger effect of capital losses associated with falling house prices than of capital gains. The literature suggests that household behavior is consistent with the view that households observe changes in general house-price levels, are aware of the probable implications for the value of their own home and adjust their consumption expenditures accordingly.

If this is correct, then one must also reconsider the large amounts of home equity of elderly households. Most of this equity was accumulated as a consequence of the substantial increase in house prices in the 1990s, which was probably in large part unexpected by these households. One would therefore expect an effect of the still-high level of house prices on the expenditure of these households, and this would suggest that many of them take up part of this equity. The popularity of interest-only mortgages among elderly households suggests that this effect is indeed to some extent present (see Rouwendal (2007b)).

\subsection{House-Price Insurance and Housing-Market Derivatives}

If households adjust their consumption to changing house prices (and the previous section indicates that this is the case), then they probably

44 See, however, Attanasio et al. (2005a).

45 For instance, Case et al. (2001) presented macro evidence referring to 14 countries; Caroll etal. (2006) used an alternative method to measure it, and found a substantial effect. 
dislike uncertainty with respect to house prices. For instance, the asymmetry observed by Engelhardt (1996b) is suggestive of risk-aversion. One might therefore conjecture that households would welcome the introduction of financial products that allow them to decrease their exposure to houseprice risk.

It is clear that the traditional response of investors to mitigate risk - diversification - could work very well in the case of housing. For instance, Goetzmann (1993, Section 6) presents evidence that diversifying across four houses in different geographical markets may reduce risks dramatically. The 'housing partnerships' proposed by Caplin et al. (1997) may thus have a bright future. However, 10 years after their book appeared, this idea is not widely accepted. Although the reasons behind this failure are unclear, one might reasonably conjecture that households do not prefer a situation in which they in fact own just a part of the house they live in. Although the purchase of 'the second half of your home' may imply that you bear much more risk than if you hand it to a housing partnership in exchange for an equivalent share in other houses, the loss of ownership may be perceived as a major disadvantage. Another relevant aspect is that housing partnerships may weaken the incentives for carrying out proper maintenance of the house and for protecting its value against developments that tend to decrease its value. ${ }^{46}$ Whatever the reason, it is still current practice that homeowners bear all of the price risk associated with the house in which they live. ${ }^{47}$

Housing partnerships would offer homeowners the benefits of diversification that a large housing market offers, but would impose the constraint that households must invest the total purchase price of their house in housing. It is possible, in principle, to relax also this constraint. Since house prices are only weakly correlated with the price of other assets (stocks, bonds), there is almost surely a market for house-price derivatives. The development of such a market would open the possibility for households to abandon this constraint. This would come at the 'price' of some kind of an investment trust owning (a potentially large part of) your house. Given the failure of housing partnerships, it is perhaps hardly surprising that such proposals (made, for instance, in Englund et al. (2002) and Quigley (2006)) have yet to lead to the introduction of house-price derivatives on financial markets.

There is little doubt that such initiatives could potentially result in large gains for participating households. The computations presented in the papers referred to above were confirmed in a more recent analysis by Cauley et al.

46 Fischel (2001) contains an extensive analysis.

47 Note, however, that they are able to avoid losses to some extent - for instance, by choosing the time to sell their house and by using a reservation price. See Merlo and Ortalo-Magné (2004) for the bargaining process, in general, and Genesove and Mayer (2001) for the role of loss aversion. 
(2007), who concluded that 'homeowners would require a $6 \%$ increase in total net worth to achieve the same utility level as an individual not facing the asset allocation constraint' that they must bear the risk of their own house completely. This suggests that there exists - at least in principle - great potential for improvement of the functioning of the housing market and related markets for financial products, although this potential has, at least until now, been difficult to exploit. ${ }^{48}$

\subsection{The Future of House Prices}

Before this section concludes, some attention should be paid to the question of whether there is a relationship between ageing and house prices. This issue received a great deal of attention after the publication of Mankiw and Weil (1989), who argued that the general increase in real house prices in the US in the 1970s and 1980s was related to the appearance of the babyboom generation on the housing market. This analysis suggested that the ageing of this generation would naturally bring with it a symmetric decrease in housing prices. The results of Mankiw and Weil soon were criticized, however, and house prices in the US have tended to increase, not decrease, in real terms, until (at least) 2007. More recent developments in housingmarket analysis have tended to stress the urban context of housing markets (see, e.g. DiPasquale and Wheaton (1994)) and the asymmetry between growing- and declining markets (Glaeser and Gyourko (2005)). The former implies that house prices will tend to be higher in larger metropolitan areas because of the scarcity of land. The asymmetry is caused by the durable nature of housing, which prevents downward adjustment of the housing stock. Cheap housing, however, is an important amenity of metropolitan areas, which would otherwise decline in population, and therefore tends to mitigate urban decline. House prices in such areas do not fall much below the sum of construction costs and the opportunity cost of land.

This analysis assumes that the total population size, measured in terms of households, does not decrease - an assumption that is valid for the foreseeable future in the US and probably also for the Netherlands. ${ }^{49}$ The substantial increase in Dutch house prices throughout the 1990s should be related in the first place to the combination of increasing incomes, decreasing mortgage interest rates and tight spatial planning, rather than to increased demand for housing by the baby-boom generation. Also the relative stabilization of real house prices in the 2000s can be attributed primarily to stagnating incomes, stable low real interest rates and - again - tight spatial planning. As long as the household population does not decrease, an economic recession

48 See Caplin (2000) and Caplin et al. (2003a, b) for an extensive discussion.

49 See Van Dam and de Groot (2006). 
(particularly the combination of higher real interest rates and sharply increasing unemployment) seems to be the real risk for a decrease in house prices.

Given the tight spatial planning regime and the expected future growth of the number of households, it seems unlikely that the price of newly constructed housing will approach the sum of construction costs and opportunity cost of agricultural land. Another benchmark value is hard to define. Empirically, the average house price has been close to the ratio of average monthly income and the net (after tax) interest rate, multiplied by 0.27 (Boelhouwer et al. (2001)). Since the maximum allowable mortgage-payment-to-income ratio used in the mortgage-qualification constraint is close to 0.30 , one might say that house prices in the Netherlands are determined by demand-constrained starters who bid up house prices to the maximum they can borrow. It seems likely that this situation will continue in the near future. ${ }^{50}$

\subsection{The Place of the Housing Market in the National Economy}

The previous section studied housing demand mostly from a microeconomic perspective. This means that the role of the housing market in the macroeconomy has been ignored. The main exception is that we have pointed to the important affects of changes in the interest rate on the housing market and on the wider economy. Further discussion of these aspects is outside the scope of the present paper, but it should be mentioned that a growing literature is focusing especially on this issue. ${ }^{51}$

\section{CONCLUSIONS}

The literature discussed in the previous sections suggests strongly that housing is important both as a durable consumption good and as an asset for many households. This final section attempts to draw some conclusions with respect to housing-market policy. In doing so, we focus on the later phases of the life cycle. The context of this discussion is mainly the Dutch situation.

\subsection{Current Housing-Market Policy}

The main instruments of current Dutch housing-market policy are the rent allowance and the deductibility of paid mortgage interest. The benefits of the rent allowance depend mainly on the income of the renter. Allocation in the rental part of the housing market still relies heavily on queuing systems and points that indicate the urgency of a move, which implies that household

50 This relationship underlines the relation between interest-rate risk and house-price risk noted elsewhere in the paper.

51 See, for instance, Lustig and van Nieuwerburgh (2006) and the references cited therein. 
preferences play a limited role. The allocation system, moreover, is explicitly designed to limit the amount of rent allowance.

In contrast, the benefits of mortgage-interest deductibility can be manipulated by households to a considerable extent. The traditional linear and annuity mortgage types imply much smaller tax expenditure associated with interest deductibility over the whole mortgage term than the life insurance and investment mortgages do. ${ }^{52}$ There is little doubt that the popularity of this mortgage type in the current Dutch situation is closely related to this facility. ${ }^{53}$

It should also be noted that the current Dutch tax system contains strong incentives for owner-occupiers to maximize the amount of mortgage debt. Interest paid on mortgage loans is deductible from taxable labor income at a high marginal rate, whereas interest received on capital that is not invested in the house is taxed at a much lower marginal rate (see Rouwendal (2007a)). It is therefore beneficial for an owner-occupier to postpone repayment of the mortgage loan as long as possible, while investing the money saved in other ways. ${ }^{54}$ Since the alternative investment will often be risky, the effect of such behavior is often that the homeowner's loan-to-value ratio remains high while he invests more in risky assets. With an ARM, this also means that he bears more interest rate risk. The - probably unintended - effect of the current tax treatment of Dutch owner-occupiers is therefore that many of them bear more risk than they would otherwise do. In the current situation of volatile financial markets this may be a substantial drawback that could have been avoided by an alternative treatment of owner-occupied housing. Moreover, the increasing amount of outstanding mortgage debt erodes the income tax base.

It is apparent from the figures presented in Section 1 of this paper that the considerable benefits associated with mortgage-interest deductibility are reaped especially by middle-aged homeowners. Elderly owner-occupiers often do not have a mortgage loan, and if they have one, the amount of outstanding mortgage debt is usually lower than that of younger households. Moreover, some recent changes in the measure make it more difficult for the elderly to use this measure - to prevent them using a mortgage loan to liquidize some of the considerable amount of equity they have accumulated in their

52 Life insurance and investment mortgages are not repaid until the end of their term. They allow the homeowner to take maximum advantage of the tax deductibility of mortgage interest Footnote 52 continued

payments while benefiting at the same time from the tax exemption of interest paid on life insurance accounts or the high (expected) returns on stocks.

53 See also Hendershott and Pryce (2006) for UK evidence.

54 A simple example in Rouwendal (2007a) suggests that this will be beneficial even if the savings are put on a bank account with an interest rate that is slightly lower than the mortgage interest rate. 
houses. In 2001, the Dutch government introduced a number of limitations on mortgage-interest deductibility: interest paid on a given mortgage loan is deductible from taxable income for at most 30 years. Moreover, interest paid on a mortgage loan is tax-deductible only if it is used for the purchase of the first owner-occupied house, or to finance the difference between the price of the new house and the revenues received from the old house, or to finance improvements in the current house. This means, for instance, that elderly homeowners who consider the use of a reverse mortgage to supplement their pension income, are now unable to make use of mortgage-interest deductibility. Since it has been argued above that there may be a latent demand for reverse mortgages and flexible credit arrangements for elderly households facing illness or death of one partner, it may be worthwhile to reconsider this issue.

Apart from the measures directed at housing costs, Dutch housing policy is involved in the construction of housing through spatial planning. This part of housing policy attempts to protect open space in the densely populated country, while at the same time offering each household the possibility to live in a decent house. There are clear indications that this policy has contributed much to the present high level of house prices in the Netherlands (see Vermeulen and Rouwendal (2007)) and, through this, to the large amounts of equity accumulated in the houses of owner-occupiers. On the one hand, this is highly beneficial for homeowners, some of whom have realized substantial increases in home equity. On the other hand, it is somewhat problematic for renters, especially when they want to switch to the owner-occupied sector.

Finally, we should of course mention the NHG (discussed in Section 3), which removed the down-payment constraint from the Dutch housing market. This measure facilitates entrance to the owner-occupied part of the market. It is therefore of particular relevance to young owner-occupiers. It might be worthwhile to consider whether a similar guarantee for reverse mortgages or flexible lines of credit for elderly households could improve the functioning of this segment of the housing finance market.

In conclusion it must be said that the tax treatment of Dutch owneroccupiers and spatial planning rules and procedures have a strong impact on Dutch house prices. Changes in these policy measures could improve the efficiency of the housing market, but also have potentially large effects on house prices and, as a consequence, on the housing wealth of owner-occupiers. Knowledge of these effects seems to be limited and it would clearly be wise to consider theme carefully before implementing changes in - say - the tax deductibility of mortgage interest paid. 


\subsection{Outlook}

In years to come, the share of elderly owner-occupiers in the Dutch population will increase steadily. These households may be expected to have strong preferences for staying in their current home for as long as possible. Many of these households have only a limited amount of mortgage debt and will become outright owners in the course of time. If real house prices remain at the current high level, most of these households will own a substantial amount of home equity.

At the same time, it must also be expected that the number of elderly households that need long-term care services will increase considerably. ${ }^{55}$ The increased need for care of elderly people will impose a growing burden on Dutch society, as it will do in many other countries. Could this burden be relieved through the use of the apparently under-utilized home equity of the elderly households?

It is not easy to assess the potential for such measures and the welfare benefits that may be realized. Earlier in this paper we explained how the mortgage guarantee provided by the Dutch government has successfully removed a borrowing constraint and thereby improved the functioning of the mortgage market to the benefit of many and at very low cost. It is doubtful whether any economist could have predicted this success ex ante. We also described how forceful arguments in favor of house-price insurance and house-price derivatives have not resulted in significant innovations, despite the enormous benefits that might have been realized. Although the proponents of such new products may have underestimated some of the drawbacks associated with the innovations they suggest, major difficulties seem also to be associated with what may be called the behavioral aspects involved. Human beings are not sophisticated rational computers, but act on the basis of a variety of considerations. The use of rules-of-thumb may in some cases lead to considerable welfare losses. Consider, for example, the extensive costs associated with the consumption constraint on investments in owner-occupied housing. Yet, it is also clear that such rules may help households to survive in less-thanconvenient conditions (they don't have to reconsider their decisions continuously) in a very complicated environment that is only partly understood and whose future development is hard to predict. Leaving the equity accumulated in one's own house in large part untouched until unexpected events force a household to use this resource may well be a good example. In the words of Skinner (2007):

... [P]lanning for consumption smoothing doesn't mean one has to maintain consumption spending through retirement. One could 
plan on getting by with less just after retirement [...], while leaving some assets for future contingencies. Housing wealth is ideal for this type of risk, since equity in the house can be directly transferred to purchase an apartment in an assisted living development, or to help pay nursing home bills. (p. 21)

This suggests that what seems to be suboptimal behavior may in fact offer adequate and reasonable protection against (some aspects of) unpleasant contingencies.

Campbell (2006) argued that economists might view it as part of their professional task to assist households in taking adequate decisions. In doing so, they will have to take into account the fact that their models may lack details (such as transaction costs) that help to keep them tractable, but that may also result in a gap between model predictions and what is in fact optimal. This means that providing advice to economic actors - politicians as well as households - may prove to be more difficult than it appears at first sight.

Recent research has stressed that financial literacy (Lustig and van Nieuwerburgh (2006)), cognitive abilities (Christelis et al. (2006)) and being middleaged (Agarwal et al. (2007)) are factors that help an individual to make adequate decisions. Households have usually chosen their housing-tenure type before the arrival of middle age, and those who become owner-occupiers have on average higher incomes - and therefore probably better cognitive abilities and a higher level of financial literacy - than others. Policies to improve the use made of housing equity seem to have the best chance if they are directed toward this group. Many of the households in that group already live in the house in which they will grow old after retirement. ${ }^{56}$

The current welfare system in the Netherlands provides a basic package of medical services for everyone at the same prices. Additional services can be purchased by the households themselves, and are often provided through private insurance. There is some concern about the sustainability of this system in the medium run that is closely related to the ageing of the population. It may be possible to design packages that facilitate the strong desire of homeowners for 'aging in place' through the use of their home equity. The optional provision of such package, financed partly by home equity, may improve the homeowners' well-being while at the same time relieving the burden associated with universal provision of the standard package. The detailed elaboration of such possibilities (let alone an assessment of their marketability) is, however, outside the scope of this paper.

56 One possible objection against considering policy measures that are especially directed towards homeowners, is that this group is in many respects better off than others. Note, however, that such measures do not necessarily imply that other groups will become worse off. 
Acknowledgements Comments by Jan Brueckner, Henk Don, Thies Lindenthal, Rick van der Ploeg, Lou Spoor and two anonymous referees on an earlier version are gratefully acknowledged.

Open Access This article is distributed under the terms of the Creative Commons Attribution Noncommercial License which permits any noncommercial use, distribution, and reproduction in any medium, provided the original author(s) and source are credited.

\section{REFERENCES}

Abraham, J.M. and P.H. Hendershott (1996), 'Bubbles in Metropolitan Housing Markets', Journal of Housing Research, 7, pp. 191-208.

Agarwal, S., J. Driscoll, X. Gabaix and D. Laibson (2007), 'The Age of Reason: Financial Decisions over the Life Cycle', NBER Discussion Paper 13191.

Aldershof, T., R. Alessie and A. Kapteyn (1996), 'Female Labor Supply and the Demand for Housing', Working Paper, CentER, Tilburg University.

Alessie, R., S. Hochguertel and A. van Soest (2002), 'Household Portfolios in the Netherlands', in: L. Guiso, M. Haliassos and T. Japelli (eds.), Household Portfolios, MIT Press, Cambridge, MA, Chapter 9, pp. 341-388.

Alessie R. and A. Kapteyn (2002), Huizenprijzen en Besparingen (House Prices and Savings). Preadvies voor de Nederlandse Vereniging voor Staathuishoudkunde.

Ameriks, J., A. Caplin, S. Laufer and S. van Nieuwerburgh (2007), 'The Joy of Giving or Assisted Living? Using Strategic Surveys to Separate Bequest and Precautionary Motives', Working Paper.

Artle, R. and P. Varaiya (1978), 'Life Cycle Consumption and Home Ownership', Journal of Economic Theory, 18, pp. 38-58.

Attanasio, O.P., L. Blow, R. Hamilton and A. Leicester (2005a), 'Booms and Busts: Consumption, House Prices and Expectations', IFS Working Paper 05/25.

Attanasio, O., R. Bottazzi, H. Low, L. Nesheim and M. Wakefield (2005b), 'Explaining LifeCycle Profiles of Home-Ownership and Labour Supply', Working Paper.

Attanasio, O.P. and G. Weber (1994), 'The UK Consumption Boom of the Late 1980s: Aggregate Implications of Microeconomic Evidence', Economic Journal, 104, pp. 1269-1302.

Bajari, P., C. Lanier Benkard and J. Krainer (2005), 'House Prices and Consumer Welfare', Journal of Urban Economics, 58, pp. 474-487.

Banks, J., R. Blundell, Z. Oldfield and J.P. Smith (2004), 'House Price Volatility and Housing Ownership Over the Life Cycle', UCL Discussion Paper 04-09.

Bloemen, H. (2007), 'The Impact of Wealth on Job Exit Rates of Elderly Workers', TI Discussion Paper 2007-002/3.

Boehm, T.P. (1993), 'Income, Wealth Accumulation and First-Time Homeownership: An Intertemporal Analysis', Journal of Housing Economics, 3, pp. 16-30.

Boelhouwer, P., M.E.A. Haffner, P. Neuteboom and P. de Vries (2001), 'Koopprijsontwikkeling en de Fiscale behandeling van het Eigen Huis. (House Price Development and the Fiscal Treatment of Owner-Occupied Housing, in Dutch)', Final Report, OTB Delft.

Bottazzi, R. (2004), 'Labour Market Participation and Mortgage Related Borrowing Constraints', IFS Working Paper 04/09. 
Browning, M. and A. Lusardi (1996), 'Household Saving: Micro Theories and Micro Facts', Journal of Economic Literature, 34, pp. 1797-1855.

Browning, M. and C. Meghir (1991), 'Testing for Separability Between Goods and Leisure Using Conditional Demand Systems', Econometrica, 59, pp. 925-952.

Brueckner, J.K. (1986), 'The Downpayment Constraint and Housing Tenure Choice', Regional Science and Urban Economics, 16, pp. 519-525.

Brueckner, J.K. (1994), 'The Demand for Mortgage Debt: Some Basic Results', Journal of Housing Economics, 3, pp. 251-262.

Brueckner, J.K. (1997), 'Consumption and Investment Motives and the Portfolio Choices of Homeowners', Journal of Real Estate Finance and Economics, 15, pp. 159-180.

Brueckner, J.K. and J.R. Follain (1988), 'The Rise and Fall of the ARM: An Econometric Analysis of Mortgage Choice', Review of Economics and Statistics, 70, pp. 93-102.

Brueckner, J.K. and J.R. Follain (1989), 'ARMs and the Demand for Housing', Regional Science and Urban Economics, 19, pp. 163-187.

Campbell, J.Y. (2006), 'Household Finance', Journal of Finance, 61, pp. 1553-1604.

Campbell, J.Y. and J.F. Cocco (2003), 'Household Risk Management and Optimal Mortgage Choice', Quarterly Journal of Economics, 118, pp. 1449-1494.

Campbell, J.Y. and J.F. Cocco (2006), 'How Do House Prices Affect Consumption? Evidence from Micro Data', Journal of Monetary Economics, 54, pp. 591-621.

Campbell, J.Y. and L.M. Viceira (2002), Strategic Asset Allocation, Oxford University Press, Oxford

Caplin, A.S. (2000), 'Inertia in the US Housing Finance Market: Causes and Consequences', Working Paper.

Caplin, A., S. Chan, C. Freeman and J. Tracey (1997), Housing Partnerships, MIT Press, Cambridge, MA.

Caplin, A., W. Goetzmann, E. Hangen, B. Nalebuff, E. Prentice, J. Rodkin, M. Spiegel and T. Skinner (2003a), 'Home Equity Insurance: A Pilot Project', Yale ICF Working Paper 03-12.

Caplin, A., C. Joyce, P. Butt, E. Glaeser and M. Kuczynski (2003b), 'Innovative Approaches to Reducing the Cost of Homeownership', Menzies Research Center.

Capozza, D.R., P.H. Hendershott and C. Mack (2004), 'An Anatomy of Price Dynamics in Illiquid Markets: Analysis and Evidence from Local Housing Markets', Real Estate Economics, 32, pp. $1-32$.

Caroll, C.D., M. Otsuka and J. Slacalek (2006), 'How Large is the Housing Wealth Effect? A New Approach', Working Paper.

Carstensen, L.L. (2006), 'The Influence of a Sense of Time on Human Development', Science, 312, pp. 1913-1915.

Case, K.E. and R. Shiller (1989), 'The Efficiency of the Market for Single Family Homes', American Economic Review, 79, pp. 125-137.

Case, K.E., J.M. Quigley and R. J. Shiller (2001), 'Comparing Wealth Effects: The Stock Market versus the Housing Market', Advances in Macroeconomics, 5, pp. 1235-1255.

Cauley, S.D., A. Pavlov and E.S. Schwartz (2007), 'Homeownership as a Constraint on Asset Allocation', Journal of Real Estate Finance and Economics, 34, pp. 283-311.

Chetty, R. and A. Szeidl (2007), 'Marriage, Housing and Portfolio Choice: A Test of GrossmanLaroque', Working Paper.

Christelis, D., T. Japelli and M. Padula (2006), 'Cognitive Abilities and Portfolio Choice', CEPR Discussion Paper 5735. 
Clark, W.A.V. and M.C. Deurloo (2006), 'Aging in Place and Housing Over-Consumption', Journal of Housing and the Built Environment, 21, pp. 257-270.

Cocco, J.F. (2005), 'Portfolio Choice in the Presence of Housing', Review of Financial Studies, 18, pp. $535-567$.

Coile, C. and K. Milligan (2006), 'How Household Portfolios Evolve After Retirement: The Effect of Aging and Health Shocks', NBER Working Paper 12391.

Coulibaly, B. and G. Li (2006), 'Do Homeowners Increase Consumption After the Last Mortgage Payment? An Alternative Test of the Permanent Income Hypothesis', Review of Economics and Statistics, 88, pp. 10-19.

Davidoff, T. (2006), 'Labor Income, Housing Prices, and Homeownership', Journal of Urban Economics, 59, pp. 209-235.

Deaton, A. (1992), Understanding Consumption, Oxford University Press, Oxford.

Del Boca, D. and A. Lusardi (2003), 'Credit Market Constraints and Labor Market Decisions', Labour Economics, 10, pp. 681-703.

Deng, Y., J.M. Quigley and R. Van Order (2000), 'Mortgage Terminations, Heterogeneity and the Exercise of Mortgage Options', Econometrica, 68, pp. 275-307.

Diaz-Serrano, L. (2005), 'On the Negative Relationship Between Labor Income Uncertainty and Homeownership: Risk-Aversion vs. Credit Constraints', Journal of Housing Economics, 14, pp. $109-126$.

Dietz, R.D. and D.R. Haurin (2003), 'The Social and Private Micro-Level Consequences of Homeownership', Journal of Urban Economics, 54, pp. 401-450.

DiPasquale, D. and W.C. Wheaton (1994), 'Housing Market Dynamics and the Future of Housing Prices', Journal of Urban Economics, 35, pp. 1-28.

Doling, J. and N. Horsewood (2003), 'Home Ownership and Early Retirement: European Experience in the 1990s', Journal of Housing and the Built Environment, 18, pp. 289-308.

Engelhardt, G. (1996a), 'Consumption, Down Payments and Liquidity Constraints', Journal of Money, Credit and Banking, 28, pp. 255-271.

Engelhardt, G. (1996b), 'House Prices and Home Owner Saving Behavior', Regional Science and Urban Economics, 26, pp. 313-336.

Engelhardt, G. (2008), 'Social Security and Elderly Homeownership', Journal of Urban Economics, 63, pp. 280-305.

Englund, P., M. Hwang and J.M. Quigley (2002), 'Hedging Housing Risk, Journal of Real Estate Finance and Economics, 24, pp. 167-200.

Fischel, W.A. (2001), The Homevoter Hypothesis, Harvard University Press, Cambridge, MA.

Fisher, J.D., D.S. Johnson, J.T. Marchand, T.M. Smeeding and B.B. Torrey (2007), 'No Place Like Home: Older Adults and Their Housing', Journal of Gerontology (Social Sciences), 62B, S120-S128.

Flavin, M. and S. Nakagawa (2004), 'A Model of Housing in the Presence of Adjustment Costs: A Structural Model of Habit Persistence', NBER Working Paper 10458.

Flavin, M. and T. Yamashita (2002), 'Owner-Occupied Housing and the Composition of the Household Portfolio', American Economic Review, 92, pp. 345-362.

Fortin, N. (1995), 'Allocation Inflexibilities, Female Labor Supply, and Housing Asset Accumulation: Are Women Working to Pay the Mortgage?', Journal of Labor Economics, 13, pp. 524-557.

Genesove, D. and C. Mayer (2001), 'Nominal Loss Aversion and Seller Behavior: Evidence from the Housing Market', Quarterly Journal of Economics, 116, pp. 1233-1260. 
Gerardi, K., H.S. Rosen and P. Willen (2007), 'Do Households Benefit from Financial Deregulation and Innovation? The Case of the Mortgage Market', NBER Working Paper 12967.

Glaeser, E.L. and J. Gyourko (2005), 'Urban Decline and Durable Housing', Journal of Political Economy, 113, pp. 345-375.

Glaeser, E.L. and J. Gyourko (2007), 'Housing Dynamics', Harvard Institute of Economic Research Discussion Paper 2137.

Goetzmann, W.N. (1993), 'The Single Family Home in the Investment Porfolio', Journal of Real Estate Finance and Economics, 6, pp. 201-222.

Goodman, J.C. and J.B. Ittner (1992), 'The Accuracy of Home Owners' Estimates of House Value', Journal of Housing Economics, 2, pp. 339-357.

Green, R.K. and S.M. Wachter (2005), 'The American Mortgage in Historical and International Context', Journal of Economic Perspectives, 19, pp. 93-114.

Grossman, S.J. and G. Laroque (1990), 'Asset Pricing and Optimal Portfolio Choice in the Presence of Illiquid Durable Consumption Goods', Econometrica, 58, pp. 25-51.

Gyourko, J., C. Mayer and T. Sinai (2006), 'Superstar Cities', NBER Working Paper 12355.

Haffner, M.E.A. (2005), Appel voor de Dorst? (Savings for a Rainy Day?). DGW/NETHUR (in Dutch).

Heiss, F., M. Hurd and A. Börsch-Supan (2003), 'Health, Wealthy and Knowing Where to Live: Predicted Trajectories of Health, Wealth and Living Arrangements Among the Oldest Olds', NBER Working Paper 9897.

Hendershott, P.H. and G. Pryce (2006), 'The Sensitivity of Homeowner Leverage to the Deductibility of Home Mortgage Interest', Journal of Urban Economics, 60, pp. 50-68.

Henderson, J.V. and Y.M. Ioannides (1983), 'A Model of Housing Tenure Choice', American Economic Review, 73, pp. 98-113.

Hu, X. (2005), 'Portfolio Choices for Homeowners', Journal of Urban Economics, 58, pp. 114-136.

Hurd, M.D. (1999a), 'Portfolio Holdings by the Elderly', Working Paper.

Hurd, M.D. (1999b), 'Mortality Risk and Consumption by Couples', NBER Working Paper 7048.

Hurd, M.D. (1999c), 'Anticipated and Actual Bequests', NBER Working Paper 7380.

Iacoviello, M. and F. Ortalo-Magné (2003), 'Hedging Housing Risk in London', Journal of Real Estate Finance and Economics, 27, pp. 191-209.

Ioannides, Y.M. (1988), 'Life Cycle Consumption, Labor Supply and Housing', Annales d'Economie et de Statistique, 9, pp. 93-110.

Jackman, R. and J. Sutton (1982), 'Imperfect Capitcal Markets and the Monetarist Black Box: Liquidity Constraints, Inflation and the Asymmetric Effects of Interest Rate Policy', Economic Journal, 92, pp. 108-128.

Jones, L.D. (1990), 'Current Wealth Constraints on the Housing Demand of Young Owners', Review of Economics and Statistics, 72, pp. 424-432.

Jones, L.D. (1993), 'The Demand for Home Mortgage Debt', Journal of Urban Economics, 33, pp. $10-28$.

Jones, L.D. (1995a), 'Testing the Central Prediction of Housing Tenure Transition Models', Journal of Urban Economics, 38, pp. 50-73.

Jones, L.D. (1995b), 'Net Wealth, Marginal Tax Rates and the Demand for Home Mortgage Debt', Regional Science and Urban Economics, 25, pp. 297-322. 
Kohlhase, J.E. (1986), 'Labor Supply and Housing Demand for One- and Two-Earner Households', Review of Economics and Statistics, 68, pp. 48-57.

Koijen, R.S.J, O. van Hemert and S. van Nieuwerburgh (2007), 'Mortgage Timing', NBER Working Paper 13361.

Lamont, O. and J. Stein (1999), 'Leverage and House-Price Dynamics in US Cities', RAND Journal of Economics, 30, pp. 498-514.

Lusardi, A. and O.S. Mitchell (2006), 'Baby Boomer Retirement Security: The Roles of Planning, Financial Literacy, and Housing Wealth', NBER Working Paper 12585.

Lustig, H. and S. van Nieuwerburgh (2006), 'Can Housing Collateral Explain Long-Run Swings in Asset Returns?', NBER Working Paper 12766.

Malpezzi, S. (1999), 'A Simple Error Correction Model of House Prices', Journal of Housing Economics, 8, pp. 27-62.

Mankiw, N.G. and D.N. Weil (1989), 'The Baby Boom, the Baby Bust and the Housing Market', Regional Science and Urban Economics, 19, pp. 235-258.

Martin, R.F. (2003), 'Consumption, Durable Goods, and Transaction Costs', International Finance Discussion Paper 756.

Mayer, C.J. and C.T. Somerville (2000), 'Residential Construction: Using the Urban Growth Model to Estimate Housing Supply', Journal of Urban Economics, 48, pp. 85-109.

Megbolugbe, I.F., J. Sa-Aadu and J. Shilling (1997), 'Oh Yes, the Elderly Will Reduce Housing Equity Under the Right Circumstances', Journal of Housing Research, 8, pp. 53-74.

Merlo, A. and F. Ortal-Magne (2004), 'Bargaining over Residential Real Estate: Evidence from England', Journal of Urban Economics, 56, pp. 192-216.

Muellbauer, J. and A. Murphy (1990), 'Is the UK Balance of Payments Sustainable?', Economic Policy, 11, pp. 345-383.

Ortalo-Magné, F. and S. Rady (2006), 'Housing Market Dynamics: On the Contribution of Income Shocks and Credit Constraints', Review of Economic Studies, 73, pp. 459-485.

Palumbo, M.G. (1999), 'Uncertain Medical Expenses and Precautionary Saving Near the End of the Lifecycle', Review of Economic Studies, 66, pp. 395-421.

Pelizzon, L. and G. Weber (2006a), 'Are Household Portfolios Efficient? An Analysis Conditional on Housing', Working Paper.

Pelizzon, L. and G. Weber (2006b), 'Efficient Portfolios When Housing Needs Change Over the Life Cycle', Working Paper.

Phillips, R.A. and J.H. Vanderhoff (1991), 'Two-Earner Households and Housing Demand: The Effect of the Wife's Occupational Choice', Journal of Real Estate Finance and Economics, 4, pp. 83-91.

Piskorski, T. and A. Tchistyi (2006) 'Optimal Mortgage Design', Working Paper.

Plaut, S.E. (1984), 'Endogeneous Mortgage Interest and the Consumption of Housing', Journal of Urban Economics, 16, pp. 31-45.

Portrait, F., M. Lindeboom and D. Deeg (2000), 'The Use of Long-Term Care Services by the Dutch Elderly', Health Economics, 9, pp. 513-531.

Poterba, J.M. (1984), 'Tax Subsidies to Owner-Occupied Housing: An Asset-Market Approach', Quarterly Journal of Economics, 99, pp. 729-752.

Quigley, J.M. (2002), 'Transaction Costs and Housing Markets', in: A. O'Sullivan and K. Gibb (eds.), Housing Economics and Public Policy, Blackwell, Oxford, pp. 56-64.

Quigley, J.M. (2006), 'Real Estate Portfolio Allocation: The European Consumer's Perspective', Journal of Housing Economics, 15, pp. 169-188. 
Quigley, J.M. and R. Van Order (1991), 'Default on Mortgage Obligations and Capital Requirements for US Savings Institutions', Journal of Public Economics, 44, pp. 353-369.

Ranney, S.I. (1981), 'The Future Price of Houses, Mortgage Market Conditions, and the Returns to Homeownership', American Economic Review, 71, pp. 323-333.

Rouwendal, J. (2007a), 'Mortgage Interest Deductibility and Homeownership in the Netherlands', Journal of Housing and the Built Environment, 22, pp. 369-382.

Rouwendal, J. (2007b), 'Ageing, Homeownership and Mortgage Choice in the Netherlands', Working Paper.

Rouwendal, J. and R. Alessie (2003), 'House Prices, Second Mortgages and Household Savings: An Empirical Investigation for the Netherlands, 1987-1994', TI Discussion Paper 074/3.

SCP. (2004), Met zorg gekozen? (Chosen with Care?). Min. VROM (in Dutch).

Sheiner, L. (1995), 'House Prices and the Savings of Renters', Journal of Urban Economics, 38, pp. $94-125$.

Shilling, J.D., U.S. Dhilon and C.F. Sirmans (1987), 'Choosing Between Fixed and Adjustable Rate Mortgages', Journal of Money, Credit and Banking, 19, pp. 260-267.

Sinai, T. and S. Souleles (2005), 'Owner-Occupied Housing as a Hedge Against Rent Risk', Quarterly Journal of Economics, 120, pp. 763-789.

Skinner, J. (1989), 'Housing Wealth and Aggregate Saving', Regional Science and Urban Economics, 19, pp. 305-324.

Skinner, J. (2007), 'Are You Sure You're Saving Enough for Retirement?', NBER Working Paper 12981.

Stein, J. (1995), 'Prices and Trading Volume in the Housing Market: A Model with DownPayment Effects', Quarterly Journal of Economics, 110, pp. 379-406.

Van Dam, F. and C. de Groot (2006), Krimp en Ruimte (Decline and Space). RPB/NAi (in Dutch).

van der Schors, A., R.J.M. Alessie and M. Mastrogiacomo (2007), 'Home and Mortgage Ownership of the Dutch Elderly: Explaining Cohort, Time and Age Effects', De Economist, 155, pp. $99-121$.

Van Hemert, O., F. de Jong and J. Driessen (2005), 'Dynamic Portfolio and Mortgage Choice for Homeowners', Working Paper.

Venti, S.F. and D.A. Wise (1990), 'But They Don't Want to Reduce Housing Equity', in: D.A. Wise (ed.), Issues in the Economics of Aging, University of Chicago Press, Chicago, pp. 13-29.

Venti, S. and D.A. Wise (2000), 'Aging and Housing Equity', NBER Working Paper 7882.

Vermeulen, W. and J. Rouwendal (2007), 'Housing Supply and Land Use Regulation in the Netherlands', TI Discussion Paper 07-058/3.

Yamashita, T. (2003), 'Owner-Occupied Housing and Investement in Stocks: An Empirical Test', Journal of Urban Economics, 53, pp. 220-237. 